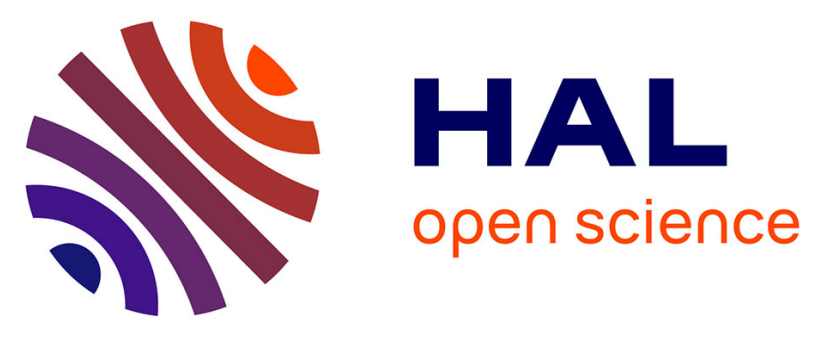

\title{
H2 production under gamma irradiation of a calcium aluminate cement: an experimental study on both cement pastes and its stable hydrates
}

Loren Acher, Marie-Noëlle de Noirfontaine, David Chartier, Dominique Gorse -Pomonti, Mireille Courtial, Sandrine Tusseau-Nenez, Olivier Cavani, Jérémy Haas, Adeline Dannoux- Papin, Frédéric Dunstetter

\section{To cite this version:}

Loren Acher, Marie-Noëlle de Noirfontaine, David Chartier, Dominique Gorse -Pomonti, Mireille Courtial, et al.. H2 production under gamma irradiation of a calcium aluminate cement: an experimental study on both cement pastes and its stable hydrates. Radiation Physics and Chemistry, 2021, 189, pp.109689. 10.1016/j.radphyschem.2021.109689 . hal-03282432

\section{HAL Id: hal-03282432 https://hal.science/hal-03282432}

Submitted on 9 Jul 2021

HAL is a multi-disciplinary open access archive for the deposit and dissemination of scientific research documents, whether they are published or not. The documents may come from teaching and research institutions in France or abroad, or from public or private research centers.
L'archive ouverte pluridisciplinaire HAL, est destinée au dépôt et à la diffusion de documents scientifiques de niveau recherche, publiés ou non, émanant des établissements d'enseignement et de recherche français ou étrangers, des laboratoires publics ou privés. 


\title{
$\mathrm{H}_{2}$ production under gamma irradiation of a calcium aluminate cement: an experimental study on both cement pastes and its stable hydrates
}

\author{
${ }^{1,2}$ Loren Acher, ${ }^{1 *}$ Marie-Noëlle de Noirfontaine, ${ }^{2}$ David Chartier, ${ }^{1}$ Dominique Gorse - Pomonti, \\ ${ }^{1,3}$ Mireille Courtial, ${ }^{4}$ Sandrine Tusseau-Nenez, ${ }^{1}$ Olivier Cavani, ${ }^{2}$ Jérémy Haas, ${ }^{2}$ Adeline Dannoux- \\ Papin, ${ }^{1}$ Frédéric Dunstetter
}

${ }^{1}$ Laboratoire des Solides Irradiés, CEA-DRF-IRAMIS, CNRS, Ecole Polytechnique,

Institut Polytechnique de Paris, 91120 Palaiseau, France

${ }^{2}$ CEA, DES, ISEC, DE2D, SEAD, LCBC, Univ Montpellier, Marcoule, France

${ }^{3}$ Université d'Artois, 1230 Rue de l'Université, F-62408 Béthune, France

${ }^{4}$ Laboratoire de Physique de la Matière Condensée, CNRS, Ecole Polytechnique,

Institut Polytechnique de Paris, 91120 Palaiseau, France

*Corresponding author: Marie-Noëlle de Noirfontaine
E-mail address: marie-noelle.de-noirfontaine@ polytechnique.edu

\begin{abstract}
The objective of this paper is to investigate the use of calcium aluminate cements as alternative cements within the context of nuclear waste stabilization by solidification. Using an external ${ }^{60} \mathrm{Co}$ source, the effect of $\gamma$-radiation on $\mathrm{H}_{2}$ gas production of one of the calcium aluminate cement-based materials (cement "Ciment Fondu") and its stable hydrates, was studied. The amount of $\mathrm{H}_{2}$ produced by these cement pastes is found to be much lower (up to five times less) than that of the Portland cement pastes containing the same amount of water, especially in the low range of water to cement ratios $(\mathrm{W} / \mathrm{C} \leq 0.4)$ where water is essentially engaged in the hydrates. The $\mathrm{H}_{2}$ production of the two major hydrates of Ciment Fondu, gibbsite $\mathrm{AH}_{3}$ and katoite hydrogarnet $\mathrm{C}_{3} \mathrm{AH}_{6}$, is very low compared with that of the main hydrates of other cements (Portland cement, Calcium Sulfo-Aluminate and Magnesium Phosphate cements). The type of water engaged in the hydrates, as hydroxyl groups and/or molecular water, influences significantly the $\mathrm{H}_{2}$ production. Thus, the nature of the hydrate is a key parameter to the aim of optimizing cement matrices with respect to the gas production under irradiation. XRD analysis shows that the crystal structures of gibbsite and katoite are preserved up to very high doses under electron irradiation ( 3 GGy). This makes calcium aluminate cements (CAC) potential good candidates for nuclear waste conditioning from the point of view of their stability under irradiation.
\end{abstract}

Keywords: Radiolysis, gamma irradiation, hydrogen, calcium aluminate cement, $\mathrm{AH}_{3}$ gibbsite, $\mathrm{C}_{3} \mathrm{AH}_{6}$ hydrogarnet katoite 


\section{Introduction}

For decades now, cement matrices have been used for the conditioning of nuclear wastes, both for conditioning solid waste (technological wastes, structural waste, etc.) and for stabilization and solidification of powder or liquid waste (evaporation concentrates, sludge, ashes, ion exchange resins, etc.). Portland cement (calcium silicate cements) is by far the most widely used for conditioning lowor intermediate-level radioactive waste. Numerous studies were carried out in order to determine the impact of radiations on cement matrices and then ensure the validity and durability of this option. It appears that (i) cement mainly produces dihydrogen under irradiation by radiolytic decomposition of water present in the pastes (Bibler, 1980; Möckel and Köster, 1982), (ii) the material undergoes textural, mechanical and mineralogical modifications induced by irradiation (Craeye et al., 2015; Soo and Milian, 2001; Vodak et al., 2005). In order to prevent the risk of explosion due to an excessive release of hydrogen in a confined environment, the amount of gas produced by radiolysis within the package must be minimized, which still motivates upstream studies in order to optimize the cement pastes with respect to radiolysis (Chartier et al., 2020; Chartier et al., 2018; Kearney et al., 2020).

The composition of a cement paste strongly depends on its amount of water. A chemical water demand of cement (also called critical water, in fact a threshold) is defined (Powers and Brownyard, 1946), as the limit above which water is in excess and does not react anymore with cement. Below this limit, the paste is a mix of residual anhydrous phases, hydrates compounds, and voids; above this limit, the paste is a mix of hydrates, voids and residual water (pore water). The chemical water demand depends on the hydrate assemblage, different from one cement to another. In practice, it is often necessary to overdose the water in relation to the chemical water demand in order to ensure a good workability of the freshly prepared material. As a first approximation, many studies have assumed that only pore water contributes to radiolytic hydrogen production under gamma irradiation (Bouniol and Bjergbakke, 2008; Christensen and Bjergbakke, 1984). The residual pore water is not pure water but an aqueous solution in equilibrium with the mineral constituents of the cement pastes and thus contains soluble elements. Numerous works coupling experiments and simulations discuss the effects of $\mathrm{pH}$ conditions (El Omar et al., 2015; Offermann, 1988) or impurities such as iron (Bouniol, 2010; Bouniol et al., 2013) and sulfide anions (Bouniol et al., 2018). Two approaches were therefore considered in order to reduce the production of $\mathrm{H}_{2}$ by reducing the amount of free water: the use of additives (superplasticizers) in the formulation of Portland cements in order to reduce the amount of water in the materials while preserving their workability (Chartier et al., 2018), or the use of alternative cements with a higher chemical water demand, such as Calcium Sulfo-Aluminate cements (CSA) or Magnesium Phosphate Cements (MPC) (Bykov et al., 2020; Chartier et al., 2020). If one compares the radiolysis effect of Portland and CSA cements with different water/cement ratios (ranging from 0.2 to 0.6 ), one finds that the $\mathrm{H}_{2}$ radiolysis yields are similar and also proportional to the total amount of water present in the material. For these cements, the status of water (free water in the 
pores or bound in cement hydrates) is said to have finally no major influence on their production of $\mathrm{H}_{2}$ under gamma irradiation (Chartier et al., 2018). Compared to Portland cements, Magnesium Phosphate Cements (MPC) display lower intrinsic gamma and alpha radiolytic gas release. Their $\mathrm{H}_{2}$ radiolytic yields are significantly reduced, provided that the main part of the mixing water is consumed by $\mathrm{K}$ struvite $\mathrm{MgKPO}_{4} \cdot 6 \mathrm{H}_{2} \mathrm{O}$ formation (Chartier et al., 2020).

Alternative cements to Portland are also under consideration in order to make available cements compatible with various types of waste, typically when the basicity of Portland cement (with a very alkaline pH generally around 13) is a drawback. For instance, MPC cements, belonging to the acidbase cement family, were investigated for the solidification of nuclear wastes containing aluminum metal because of their acidic to neutral $\mathrm{pH}$ pore solutions (ranging from 4 to 9) which are in the aluminum passivation range (Cau-Dit-Coumes et al., 2014). The purpose of this paper is to study the potentiality of another family of cements, Calcium Aluminate Cements (CAC), of interest due to their high thermal resistance and to their chemical stability in severe environments, in particular in contact with acids ( $\mathrm{pH}$ between 10 and 12) and aggressive ions (sulfates and chlorides) (Ollivier and Vichot, 2008; Scrivener et al., 1999). To our knowledge, there is very little literature data on radiolysis of CACs, excepted Bibler's work on the conditioning of waste containing transuranian nuclides (Bibler, 1980). Bibler found that the gas $\left(\mathrm{H}_{2}+\mathrm{O}_{2}\right)$ yield of $\mathrm{PuO}_{2}$ doped mixtures made of $70 \%$ CAC cement (High Alumina Cement) and $30 \%$ ash $\left(0.259 \times 10^{-7} \mathrm{~mol} / \mathrm{J}\right)$ is lower than the one of a mixture with the same proportions but where aluminate cement is replaced by Portland cement $\left(0.332 \times 10^{-7} \mathrm{~mol} / \mathrm{J}\right)$, suggesting that CAC cements are good candidates to reduce the radiolytic gas generation.

CACs are produced by mixing $\mathrm{Al}_{2} \mathrm{O}_{3}$ (from 40 to 80 wt.\%) and $\mathrm{CaO}$ (from 20 to 40 wt.\%) and iron oxides $\left(\mathrm{Fe}_{2} \mathrm{O}_{3}, \mathrm{FeO}\right.$ up to 20 wt.\%). The two major oxides $\mathrm{Al}_{2} \mathrm{O}_{3}$ and $\mathrm{CaO}$ react together and produce the major phase monocalcium aluminate $\mathrm{CaAl}_{2} \mathrm{O}_{4}(\mathrm{CA})$, as the principal hydraulic phase. The hydration of $\mathrm{CA}$ first lead to the formation of two metastable hydrates $\mathrm{C}_{2} \mathrm{AH}_{8}$ and $\mathrm{CAH}_{10}$, which convert into the two stable hydrates katoite hydrogarnet $\mathrm{Ca}_{3} \mathrm{Al}_{2}(\mathrm{OH})_{12}$ and gibbsite $\mathrm{Al}(\mathrm{OH})_{3}$ referred to as $\mathrm{C}_{3} \mathrm{AH}_{6}$ and $\gamma-\mathrm{AH}_{3}$ respectively. The conversion is strongly dependent on temperature: the use of an external heat source during the curing period can accelerate the conversion of metastable hydrates into stable hydrates, so as to obtain a material only made of katoite $\left(\mathrm{C}_{3} \mathrm{AH}_{6}\right)$ and gibbsite $\left(\mathrm{AH}_{3}\right)(\mathrm{Scrivener}$ et al., 1999; Taylor, 1997). Monocarboaluminate $\mathrm{Ca}_{4} \mathrm{Al}_{2}\left(\mathrm{CO}_{3}\right)(\mathrm{OH})_{12} .5 \mathrm{H}_{2} \mathrm{O}$ (or $\mathrm{C}_{3} \mathrm{~A} \cdot \mathrm{CaCO}_{3} \cdot 11 \mathrm{H}_{2} \mathrm{O}$ ), also referred to as monocarbonate, is also often present due to the unavoidable carbonation of katoite in the cement pastes. Recent works on irradiation of $\mathrm{AH}_{3}$ have shown that the $\mathrm{H}_{2}$ production is about $10^{-9} \mathrm{~mol} / \mathrm{J}$ or quasi null, depending on irradiation settings and sample preparation (Kaddissy et al., 2017; Westbrook et al., 2015). These values are much lower than those observed recently on calcium silicate hydrate $^{1}$ (noted C-S-H), the major hydrate of Portland cement, for which the radiolytic yield

\footnotetext{
${ }^{1}$ The general formula is $(\mathrm{CaO})_{\mathrm{x}}\left(\mathrm{SiO}_{2}\right)_{\mathrm{y}}\left(\mathrm{H}_{2} \mathrm{O}\right)_{\mathrm{z}}$ with $\mathrm{C} / \mathrm{S}$ varying from 0.66 to 2
} 
varies from 0.35 to $0.6 \times 10^{-7} \mathrm{~mol} / \mathrm{J}$ (Yin et al., 2019). Such a difference in $\mathrm{H}_{2}$ production between various hydrates raises the question of the potential role of hydrates in the radiolysis process.

This study focuses on the radiolysis of one type of CAC cement, with regard to radiolysis of its main constitutive hydrates katoite and gibbsite. CAC pastes (Water to Cement ratios varying from 0.2 to 0.6 ) and synthetic hydrates were $\gamma$-irradiated and the amount of hydrogen released by radiolysis was measured. The composition of the pastes (hydrates and pore water) and of the synthetic hydrates was determined combining XRD and IR or TGA measurements. This study reveals that CAC cement produces less hydrogen than other cements under gamma irradiation (in particular Portland cement) irradiated under the same conditions. This study discusses the contribution to the $\mathrm{H}_{2}$ radiolytic yield of the hydrates and the pore water (free) of a CAC cement, as a function of the W/C ratio. Comparison is made with other Portland, CSA and MPC cements. The paper also addresses the effect of the type of water engaged in the hydrates (as hydroxyls groups and/or molecular water) on the dihydrogen radiolytic yield.

\section{Experimental}

\subsection{Material and sample preparation}

Calcium Aluminate Cement was provided by Kerneos. It is a standard low alumina CAC made with ferruginous bauxite, characterized by lowest $\mathrm{Al}_{2} \mathrm{O}_{3}$ content and highest $\mathrm{Fe}_{2} \mathrm{O}_{3}$ content than in other CACs, commercially known as "Ciment Fondu ${ }^{\circledR}$ " (for "melted cement" in French). According to Kerneos data's supplier, the composition of the "Ciment Fondu" (CF) used, labeled here as Fonduanhydrous, is: $37.5-41$ wt. $\% \mathrm{Al}_{2} \mathrm{O}_{3}, 35.5-39$ wt. $\% \mathrm{CaO}, 13-18.5$ wt. $\% \mathrm{Fe}_{2} \mathrm{O}_{3}, 3.5-5.5$ wt. \% $\mathrm{SiO}_{2}$. About $200 \mathrm{~mL}$ of cement pastes were prepared at the laboratory scale. Cement was vigorously mixed with demineralized water in a mechanical blade stirrer (Heidolph RZR 2102 control) during 5 min before being cast in $15 \mathrm{~mL}$ plastic tubes (centrifugation tubes "SuperClear" provided by VWR). Typical samples are small cylinders of $15 \mathrm{~mm}$ diameter of approximatively $11 \mathrm{~mL}$ of cement pastes. After filling, plastic tubes were immediately sealed with their caps in order to avoid desiccation of the material during hydration and storage of the sample before irradiation. Samples were heat treated at $50{ }^{\circ} \mathrm{C}$ in their airtight tubes for one week in order to form the thermodynamically stable hydrates $\mathrm{AH}_{3}$ and $\mathrm{C}_{3} \mathrm{AH}_{6}$.

After heat treatment, cement pastes were stored under endogenous conditions in their airtight centrifugation tubes before irradiation or characterization. The obtained samples are labeled Fondu-x where $\mathrm{x}$ represents the Water to Cement (W/C) ratio used in the formulation (W/C $=\mathrm{x}, \mathrm{x}=0.2$ to 0.6 ). All characterizations were done on manually dry-grounded cement pastes down to $100 \mu \mathrm{m}$ in an agate mortar, except for mercury porosimetry for which centimetric fragments were dried by lyophilization (48 hours). 
As synthetic hydrate, a commercial powder of $\mathrm{AH}_{3}$ (99.6 wt.\% purity, Merck) was used. Katoite $\left(\mathrm{C}_{3} \mathrm{AH}_{6}\right)$ and monocarboaluminate $\left(\mathrm{Ca}_{4} \mathrm{Al}_{2}\left(\mathrm{CO}_{3}\right)(\mathrm{OH})_{12} .5 \mathrm{H}_{2} \mathrm{O}\right)$ were synthesized using the experimental protocol detailed by Matschei (Matschei, 2007). $\mathrm{C}_{3} \mathrm{AH}_{6}$ was obtained by mixing

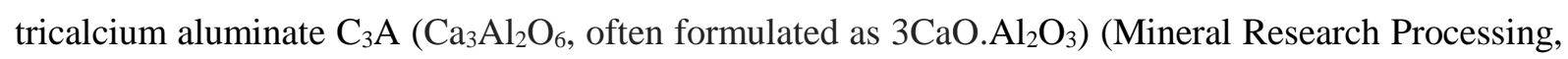
specific area $=360 \mathrm{~m}^{2} \cdot \mathrm{kg}^{-1}$ ) with boiling water and subsequent ageing at $95{ }^{\circ} \mathrm{C}$ for 7 days. Monocarboaluminate was prepared by mixing $\mathrm{C}_{3} \mathrm{~A}$ with $\mathrm{CaCO}_{3}$ (99.9 wt.\% purity, VWR Chemicals) in demineralized water, then continuously stirred for 14 days at room temperature. The powders were obtained by Büchner filtration under air for monocarboaluminate and in a glove box under $\mathrm{N}_{2}$ for katoite to prevent carbonation. They were then dried by lyophilization (freeze-drying) for two days.

\subsection{Sample characterization}

Anhydrous cement and all unirradiated cement pastes were analyzed after about one year of storage in their plastic tubes.

Identification and quantitative phase analysis were performed by X-ray diffraction and Rietveld refinements. A Panalytical diffractometer with a fast detector (X-Celerator), in the Bragg Brentano geometry $\left(\mathrm{CuK}_{\alpha}\right.$ radiation, $\lambda_{\mathrm{K} \alpha 1}=1.540596$ and $\left.\lambda_{\mathrm{K} \alpha 2}=1.544410 \AA\right)$ was used. All data were collected in the same conditions, in the angular range $5^{\circ}<2 \theta<90^{\circ}$, with step intervals of $0.02^{\circ}$ (in $2 \theta$ ) and a scan set time of 1.5 hours. Phase identifications were performed using the EVA software (version 13, Bruker-AXS, Karlsruhe, Germany, 1996-2007) and the JCPDS-International Centre for Diffraction Data ${ }^{\circledR}$ Powder Diffraction File (PDF-2, JCPDS-ICDD, Newtown Square, PA). Rietveld refinements (Rietveld, 1969) were performed using the TOPAS software (version 4, Bruker-AXS, Karlsruhe, Germany, 1996-2007) based on the fundamental parameters approach (Cheary and Coelho, 1992). The refined parameters were scale factors, zero-shift error, coefficient of the background described as a fifth order Chebychev polynomial combined with a $1 / \mathrm{X}$ term, unit cell parameters and crystallite size. The atomic positions, temperature factors and occupancy factors were kept constant in the crystal structures. Preferred orientation along [001] axis for gibbsite was corrected using March-Dollase algorithm (Dollase, 1986).

Infrared (IR) spectroscopy by ATR (Attenuated Total Reflection) experiments were performed using a Nicolet IS50 FT-IR spectrometer (Thermo Scientific) equipped with a TGS detector. Spectra were recorded by accumulating 1024 scans with a resolution of $4 \mathrm{~cm}^{-1}$ and a mirror velocity of $0.3 \mathrm{~cm} \mathrm{~s}^{-1}$ in the mid-IR $\left(500-4000 \mathrm{~cm}^{-1}\right)$. Data were analyzed using the OMNIC software.

Mercury porosimetry measurements were done with Micrometrics Autopore IV 9500 apparatus, applying a pressure $\mathrm{P}$ up to $414 \mathrm{MPa}$ allowing access to pores of 2-3 nm diameter. Pore diameter, $\mathrm{d}$, was calculated using the Washburn law considering a contact angle $\theta$ equal to $130^{\circ}$ and a surface tension $\gamma$ equal to $0.485 \mathrm{~N} . \mathrm{m}^{-1}$, according to the following equation:

$$
d=\frac{-4 \gamma \cos \theta}{P}
$$


Thermal Gravimetric Analysis (TGA) was performed in order to determine the amount of water contained in each sample. A Netzsch STA 409 instrument was used, from room temperature to $1000{ }^{\circ} \mathrm{C}$, at a heating rate of $10 \mathrm{~K} \cdot \mathrm{min}^{-1}$ under nitrogen atmosphere (flowrate $50 \mathrm{~mL} \cdot \mathrm{min}^{-1}$ ).

\subsection{Irradiation experiments}

\subsubsection{Gamma irradiation and gas analysis}

Gamma irradiations $\left({ }^{60} \mathrm{Co}\right)$ were performed at the Gammatec facility (Synergy Health, Fr) located in Marcoule, France. Dosimetry was performed as in Chartier (Chartier et al., 2018) using Perspex dosimeter supplied by Harwell (Harwell) according to the ASTM 51261 standard (ASTM). The temperature of the irradiation chamber was regulated between 20 and $25^{\circ} \mathrm{C}$.

For irradiation, $15 \mathrm{~mm}$ cylinder of cement pastes aged of minimum 1 month were demolded and placed in glass tubes of $105 \mathrm{~mL}$, deaerated (using 3 cycles of depressurization at $30 \mathrm{hPa}$ and pressurization with argon) and finally flame-sealed under $900 \mathrm{hPa}$ of pure argon (Alphagaz 1 of Air Liquide). Samples were weighted after demolding and after irradiation $(\sim 20 \mathrm{~g})$ in order to check possible desiccation, which was always found less than $1 \%$ of the total water in the cement paste. Cement paste samples Fondu-0.2, Fondu-0.3 and Fondu-0.4 were irradiated at 0.25 Gy.s. ${ }^{-1}$ up to $500 \mathrm{kGy}$ and Fondu-0.5 and Fondu-0.6 at $0.25 \mathrm{~Gy} \cdot \mathrm{s}^{-1}$ up to two doses $150 \mathrm{kGy}$ and $300 \mathrm{kGy}$. For the synthetic hydrates, $\mathrm{AH}_{3}$ was oven - dried at $150{ }^{\circ} \mathrm{C}$ for $24 \mathrm{~h}$ and $\mathrm{C}_{3} \mathrm{AH}_{6}$ and monocarboaluminate were freeze-drying for two days before sealing for irradiation. Approximatively $10 \mathrm{~g}$ of powder were irradiated at $0.17 \mathrm{~Gy} \cdot \mathrm{s}^{-1}$ up to $100 \mathrm{kGy}$ and $200 \mathrm{kGy}$. Each sample was irradiated twice in two distinct ampoules in order to check the repeatability and the validity of the irradiation procedure employed. Results show a good agreement between each batch.

Hydrogen production was measured a few weeks after irradiation by gas chromatography using a Varian CP-3800 instrument equipped with a thermal conductivity detector and a molecular sievetype column (Varian, $2 \mathrm{~m} \times 2 \mathrm{~mm}$ ), with Galaxie software. Argon was used as carrier gas. Furnace and detector temperature were $35{ }^{\circ} \mathrm{C}$ and $120{ }^{\circ} \mathrm{C}$ respectively. About $10 \mathrm{~mL}$ of gas were manually injected for each measurement. The amount of $\mathrm{H}_{2}$ (in mol. $\mathrm{kg}^{-1}$ ) was then determined according to the following equation:

$$
n\left(H_{2}\right)=\frac{P_{f} \times \%_{V o l} H_{2} \times V_{a}}{100 \times R \times T \times m_{\text {sample }}}
$$

Where $\mathrm{P}_{\mathrm{f}}$ is the gas pressure in the ampoules after irradiation, $\% \mathrm{~V}_{\mathrm{ol}} \mathrm{H}_{2}$ the volumic percentage of $\mathrm{H}_{2}$ determined by gas chromatography, $\mathrm{V}_{\mathrm{a}}$ the volume of the ampoule, $\mathrm{R}$ the gas constant, $\mathrm{T}$ the sample's temperature and $\mathrm{m}_{\text {sample }}$ the sample's mass. Finally, we determine the radiolytic yield in hydrogen $\mathrm{G}\left(\mathrm{H}_{2}\right)$ (in $\mathrm{mol} / \mathrm{J}$ ) as the slope of the gas productions versus dose $\mathrm{D}$ (in Gy) plot: 


$$
G\left(H_{2}\right)=\frac{n\left(H_{2}\right)}{D}
$$

Thus, $\mathrm{G}\left(\mathrm{H}_{2}\right)$ corresponds to the amount of hydrogen released by the material per amount of absorbed energy. The measurement error was estimated equal to $10 \%$ when the measured gas amount is larger than $10^{-9} \mathrm{~mol} / \mathrm{J}$, but was estimated to rise up to $50 \%$ when the gas amount measured was found lower than $10^{-9} \mathrm{~mol} / \mathrm{J}$.

Hydrogen radiolytic yields (in $\mathrm{mol} / \mathrm{J}$ ) can also be expressed considering the total mass of water present in the material:

$$
\frac{n\left(H_{2}\right)}{D m_{\text {total water }}}=\frac{G\left(H_{2}\right)}{w_{\text {water }}}=G\left(H_{2}\right)_{\text {normalized }}
$$

Where $\mathrm{w}_{\text {water }}$ corresponds to the mass fraction of total water in the material, allowing to define

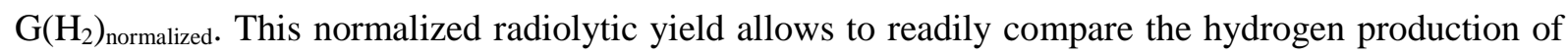
materials containing different amounts of water. For cement pastes, the total amount of water is the amount of water used in the formulation since desiccation is prevented using airtight containers for storage. For the hydrates, the total amount of water was determined experimentally by TGA considering the total weight loss up to $600{ }^{\circ} \mathrm{C}$ (considering that decomposition above $600{ }^{\circ} \mathrm{C}$ is attributed to decarbonation).

\subsubsection{Electron irradiation conditions}

Electron irradiations at $2.5 \mathrm{MeV}$ were also performed using the accelerator NEC Pelletron of the SIRIUS platform (Ecole polytechnique, France) in order to investigate the structural resistance at high doses of the two hydrates $\mathrm{AH}_{3}$ and $\mathrm{C}_{3} \mathrm{AH}_{6}$. At this energy, all electrons pass through the sample, the projected range being in the order of $4 \mathrm{~mm}$. Small pellets (13 mm diameter and $1 \mathrm{~mm}$ thickness) of $\mathrm{AH}_{3}$ and $\mathrm{C}_{3} \mathrm{AH}_{6}$ were irradiated under helium gas with the following conditions: the temperature did not exceed $43{ }^{\circ} \mathrm{C}$ and $52{ }^{\circ} \mathrm{C}$ for $\mathrm{AH}_{3}$ and $\mathrm{C}_{3} \mathrm{AH}_{6}$ respectively; the beam current was around $26 \pm 2 \mu \mathrm{A}$ and $20 \pm 2 \mu \mathrm{A}$ with the corresponding flux equal to $\sim 12 \times 10^{13} \mathrm{e}^{-} \cdot \mathrm{cm}^{-2} \cdot \mathrm{s}^{-1}$ and $10 \times 10^{13} \mathrm{e}^{-} \cdot \mathrm{cm}^{-2} \cdot \mathrm{s}^{-1}$ for $\mathrm{AH}_{3}$ and $\mathrm{C}_{3} \mathrm{AH}_{6}$ respectively. Absorbed doses were estimated using ESTAR code (Berger, 1992). The two hydrates were irradiated up to $310 \mathrm{MGy}$ and $3 \mathrm{GGy}$ (dose rate $\sim 4 \times 10^{4} \mathrm{~Gy} \cdot \mathrm{s}^{-1}$ ).

\section{Results and discussion}

\subsection{Characterization of materials}

\subsubsection{CF anhydrous and pastes composition}

The powders of Fondu-anhydrous and of the CF cement pastes were analyzed by XRD using the Rietveld method following the recommendations for CAC cement (Guirado and Gali, 2006) (Fig. 1). Because of its high iron content, Fondu-anhydrous has a very complex mineralogy, containing up to ten compounds with solid solutions and a strong overlap of the X-ray diffraction lines 
which can affect the accuracy of the results. Ten compounds were identified, in agreement with typical CAC's compositions referenced in literature (Hewlett and Liska, 2019). The structural models for anhydrous and hydrated compounds and the residues of the refinements $R_{\mathrm{wp}}$ and $\chi^{2}$, all inferior to 5 and 2 respectively, are reported in Table 1 and Table 2 . Under present hydration conditions, only the two stables hydrates gibbsite $\mathrm{AH}_{3}$ and katoite $\mathrm{C}_{3} \mathrm{AH}_{6}$ are found in our samples, in agreement with the available literature (Barnes et al., 2002; Scrivener et al., 1999). The refined unit cell parameter $a$ of the cubic katoite is approximately equal to $12.50 \AA$ versus $12.57 \AA$ in the pure katoite. This contraction of the unit cell suggests the formation of a solid solution with one or several impurities, such as $\mathrm{Si}$, combined or not with Fe impurity (Dilnesa et al., 2014; Kyono and Arora, 2019; Rickerby, 2015). It should be noticed a slight beginning of hydration of Fondu-anhydrous probably due the storage conditions during one year before XRD analysis. Very weak and broadened peaks are detected at around $2 \theta_{\mathrm{Cu}}=7^{\circ}$ and $2 \theta_{\mathrm{Cu}}=14.1^{\circ}$ only in Fondu- 0.6 paste. They are attributed to small amounts of strätlingite $\mathrm{C}_{2} \mathrm{ASH}_{8}$ which may be present in our system, resulting from the hydration of gehlenite $\mathrm{C}_{2} \mathrm{AS}\left(\mathrm{C}_{2} \mathrm{AS}+8 \mathrm{H} \rightarrow \mathrm{C}_{2} \mathrm{ASH}_{8}\right)$ which is slow at ambient temperature but activated by impurities or temperature or due to hydration of $\mathrm{C}_{2} \mathrm{~S}$ in the presence of $\mathrm{AH}_{3}\left(\mathrm{C}_{2} \mathrm{~S}+\mathrm{AH}_{3}+5 \mathrm{H} \rightarrow \mathrm{C}_{2} \mathrm{ASH}_{8}\right)$ (Barnes et al., 2002; Taylor, 1997). The carbonation effect is limited: 1 to 3 wt.\% of monocarboaluminate phase was detected in cement pastes. The peaks of perovskite phases (see Table 1) decrease progressively up to $\mathrm{W} / \mathrm{C}=0.4$ and completely disappear at $\mathrm{W} / \mathrm{C}=0.4$, which can be quite surprising in view of the literature where these phases are always described as inert phases. One wonders whether the dissolution of perovskites in these alumina cements could not be explained by incorporation of aluminum, as evidenced in a rather recent TEM study (Gloter et al., 2000) as also suggested by the SEM/EDX analysis of perovskite grains in CSA cements (Le Saout et al., 2019). The amounts of hydrates are given in Table 2. Plots of the evolution of the main anhydrous (CA) and the two major hydrated phases $\left(\mathrm{AH}_{3}\right.$ and $\left.\mathrm{C}_{3} \mathrm{AH}_{6}\right)$ weight percent in $\mathrm{CF}$ cement pastes versus W/C ratios are shown in Fig. 2. The amount of $\mathrm{AH}_{3}$ and $\mathrm{C}_{3} \mathrm{AH}_{6}$ increases with W/C ratio until reaching a plateau for W/C values above 0.4 , suggesting quasi-complete hydration above $\mathrm{W} / \mathrm{C}=0.4$.

The presence of free water in the pastes was investigated by infrared spectroscopy measurements (Fig. 3). The band at $1640 \mathrm{~cm}^{-1}$, attributed to the $\mathrm{O}-\mathrm{H}$ bending vibration of water (Bensted and Varma, 1974), is weak for samples prepared with a W/C ratio below or equal to 0.4 whereas the same band is intense and fine above, showing that free water is clearly present in Fondu- 0.5 and Fondu- 0.6 samples. Mercury porosimetry results display a change in the pore size distribution with the W/C ratio: for W/C equal to 0.4 and above, larger pores become visible (Fig. 4), which is consistent with the presence of water in excess, as free water, in this porosity. So, considering XRD, IR and mercury porosimetry results, one can deduce that free water is present, significantly, in cement pastes for W/C equal to 0.4 and above. The theoretical chemical water demand of Ciment Fondu CAC is comprised between 0.31 and 0.33 considering the formation of dominant hydrates $\left(\mathrm{C}_{3} \mathrm{AH}_{6}, \mathrm{AH}_{3}\right)$ due to hydration of $\mathrm{CA}$ (51.4 wt.\%), $\mathrm{C}_{4} \mathrm{AF}$ (8 wt.\%), and $\mathrm{C}_{12} \mathrm{~A}_{7}$ (2.4 wt.\%), according to the following equations: 


$$
\begin{aligned}
& 3 \mathrm{CA}+12 \mathrm{H} \rightarrow \mathrm{C}_{3} \mathrm{AH}_{6}+2 \mathrm{AH}_{3} \\
& 3 \mathrm{C}_{4} \mathrm{AF}+21 \mathrm{H}+\mathrm{AH}_{3} \rightarrow 4 \mathrm{C}_{3} \mathrm{AH}_{6} \\
& \mathrm{C}_{12} \mathrm{~A}_{7}+42 \mathrm{H} \rightarrow 4 \mathrm{C}_{3} \mathrm{AH}_{6}+3 \mathrm{AH}_{3}
\end{aligned}
$$

This theoretical chemical demand equal to 0.31 - 0.33 , determined while ignoring of course the microstructure and the adsorption related effects, is found a little lower than the experimental value in the range of $0.4-0.5$, determined above using IR and mercury porosimetry.

\subsubsection{Synthetic hydrates}

For commercial $\mathrm{AH}_{3}$, the gibbsite polymorph was identified by XRD as expected. The chemical composition determined by Rietveld analysis is: $97.2 \mathrm{wt} \%$ gibbsite, $2.8 \mathrm{wt} . \%$ boehmite $(\mathrm{AlO}(\mathrm{OH}))$. The composition of the $\mathrm{C}_{3} \mathrm{AH}_{6}$ samples determined by Rietveld analysis is: 96 wt. $\% \mathrm{C}_{3} \mathrm{AH}_{6}, 2$ wt.\% $\mathrm{C}_{3} \mathrm{~A}$ (unreacted anhydrous phase) and $2 \mathrm{wt} \%$ monocarboaluminate (due to carbonation). The composition of the monocarboaluminate samples also determined by Rietveld analysis is: $94 \mathrm{wt} . \%$ monocarboaluminate, $3.1 \mathrm{wt} . \% \mathrm{C}_{3} \mathrm{AH}_{6}$ and $2.5 \mathrm{wt} . \%$ calcite $\left(\mathrm{CaCO}_{3}\right)$.

TGA were also performed in order to check whether the heat treatment up to $150{ }^{\circ} \mathrm{C}$ for $\mathrm{AH}_{3}$ and the 2-days lyophilisation for $\mathrm{C}_{3} \mathrm{AH}_{6}$ and monocarboaluminate are enough to remove adsorbed water. Indeed, it is important to ensure that the amount of hydrogen measured under irradiation originates from the hydrates and not from the environment. For $\mathrm{AH}_{3}$, the TG pattern obtained on the sample previously heated at $150{ }^{\circ} \mathrm{C}$ is found in agreement with the results obtained for the synthetic $\mathrm{AH}_{3}$ reported in the literature (Fig. 5) (Brown et al., 1953; Kloprogge et al., 2002; Lodding, 1969). The total weight loss is equal to $33.5 \%$, which is in agreement with the theoretical value expected for $\mathrm{AH}_{3}$ which is $34.6 \%$. The thermal decomposition of lyophilized $\mathrm{C}_{3} \mathrm{AH}_{6}$ is in good accordance with the pattern described in the literature with a total weight loss of 27 \% (Fig. 5) (Majumdar and Roy, 1956; Passaglia and Rinaldi, 1984). In both cases, a plateau is observed up to $250{ }^{\circ} \mathrm{C}$ which means that no free or adsorbed water are observable in $\mathrm{AH}_{3}$ and $\mathrm{C}_{3} \mathrm{AH}_{6}$ samples. Consequently, if hydrogen is produced under irradiation it should be attributed to the sole hydrogen arising from the structure of the hydrate, i.e. from hydroxyl groups.

For monocarboaluminate, the two first weight losses around 180 and $250{ }^{\circ} \mathrm{C}$ correspond to dehydration and dehydroxylations respectively (Fig. 5) (Carlson and Berman, 1960; Gabrovšek et al., 2008; Ramachandran and Zhang, 1986). Contrary to what happens in the two above-mentioned hydrates, water starts to decompose at lower temperature in monocarboaluminate because of the presence of molecular water in the structure. A pre-thermal treatment up to $150{ }^{\circ} \mathrm{C}$ before irradiation being unfortunately inoperative, we admit that 2 days of lyophilisation will be sufficient in order to "dry" the sample.

\subsection{Hydrogen gas production}

\subsubsection{Preliminary experiments}


The structural stability of the hydrates was investigated by XRD prior to and following gamma irradiation, based on a first set of experiments performed up to $1 \mathrm{MGy}$ using Ionisos's industrial gamma irradiator located in Dagneux, France (dose rate: $0.17 \mathrm{~Gy} \cdot \mathrm{s}^{-1}$ ). Fig. 6 shows the X-ray diffraction patterns of $\mathrm{AH}_{3}, \mathrm{C}_{3} \mathrm{AH}_{6}$ and monocarboaluminate: they are quasi identical, showing no significant structural changes under gamma irradiation. The two major hydrates gibbsite $\mathrm{AH}_{3}$ and katoite $\mathrm{C}_{3} \mathrm{AH}_{6}$ were also irradiated at high doses under electron beam (SIRIUS platform). The crystal structures of the two hydrates are preserved up to 3GGy. Indeed, the XRD patterns (Fig. 7) show no amorphization or any phase transformation, but only a shift and some broadening of the Bragg lines as revealed by a slight evolution of the unit cell parameters and some microstructural variations. Compared to other hydrous minerals irradiated under similar conditions, gibbsite and katoite are found to be very resistant to irradiation, just like portlandite $\mathrm{Ca}(\mathrm{OH})_{2}$ and brucite $\mathrm{Mg}(\mathrm{OH})_{2}$ hydroxides (de Noirfontaine et al., 2018), but contrary to brushite $\mathrm{CaHPO}_{4} \cdot 2 \mathrm{H}_{2} \mathrm{O}$ for which amorphization occurs even at very low irradiation doses (de Noirfontaine et al., 2021).

For all samples, we also checked that the production of $\mathrm{H}_{2}$ is proportional to the dose in the range of 100 - $200 \mathrm{kGy}$ for the hydrates and 100 - $500 \mathrm{kGy}$ for the cement pastes. The number of mole of hydrogen per kilogram of material was plotted versus dose in order to determine the radiolytic yield $\mathrm{G}\left(\mathrm{H}_{2}\right)$ as the slope of the linear regression (Fig. 8).

\subsection{2. $\mathrm{H}_{2}$ production of cement pastes: effect of water content}

The hydrogen productions of CAC cement pastes under gamma rays were measured and their associated radiolytic yields determined (Table 3). In order to cover a large range on both sides of the chemical water demand of cement, different water to cement ratios were studied. Cement pastes with water content in default (W/C equal to 0.2 and 0.3 ), in large excess (W/C equal to 0.5 or 0.6 ) or slightly above the stoechiometric water demand $(\mathrm{W} / \mathrm{C} \geq 0.31)$ were prepared $(\mathrm{W} / \mathrm{C}=0.4)$. Table 3 also reports radiolytic yields for other cements, Portland cement and alternative cements CSA and MPC, irradiated in similar conditions than CAC. We observe that CAC and MPC cements are less radiolyzable under gamma irradiation than Portland and CSA cements. For a same mass fraction of water in the range of $28 \mathrm{wt} . \%$, Portland cement and CSA without calcium sulfate addition exhibit similar normalized $\mathrm{G}\left(\mathrm{H}_{2}\right)$ equal to $(0.325 \pm 0.03) \times 10^{-7} \mathrm{~mol} / \mathrm{J}$ and $(0.29 \pm 0.01) \times 10^{-7} \mathrm{~mol} / \mathrm{J}$ respectively, higher than the one obtained for CAC $(0.11 \pm 0.01) \times 10^{-7} \mathrm{~mol} / \mathrm{J}$. Comparison with MPC is less straightforward since MPC cement is not a conventional hydraulic binder such as Portland cement, CSA and CAC, but generated from acid-base reaction between $\mathrm{MgO}$ and soluble phosphoric acid salt $\left(\mathrm{KH}_{2} \mathrm{PO}_{4}\right)$. The stability of the stoichiometric MPC pastes (without segregation) requires the addition of a filler such as fly ashes which can also impact the radiolytic yield (Chartier et al., 2020).

Looking at Fig. 9 showing the $\mathrm{H}_{2}$ normalized yield of $\mathrm{CAC}$ as a function of the water content, we see that the $\mathrm{H}_{2}$ normalized yield is low at low water content and increases with the total amount of water. This can be correlated with the status of water depending on the water to cement ratio: below 
$\mathrm{W} / \mathrm{C}=0.4$, water is mainly chemically bound in the hydrates as hydroxyl groups $\left(\mathrm{AH}_{3}\right.$ and $\left.\mathrm{C}_{3} \mathrm{AH}_{6}\right)$ and above, free water is present in the porosity due to the water in excess with respect to the water chemical demand of the cement. This behavior is quite different from the one observed with Portland cement pastes according to Chartier et al. (Chartier et al., 2018) (Fig. 9) showing $\mathrm{H}_{2}$ normalized yields almost constant whatever the amount of water in the cement pastes. So, while the production of $\mathrm{H}_{2}$ under irradiation dimly depends on the status of water in Portland cement as explained by Chartier et $a l$, in CAC cement it is different. The normalized $\mathrm{H}_{2}$ radiolytic yield in CAC paste with excess water $(\mathrm{W} / \mathrm{C}=0.6)$ is very close to the one determined for Portland cements and not so far from the one of bulk water at $\mathrm{pH}=13\left(0.44 \times 10^{-7} \mathrm{~mol} / \mathrm{J}\right)\left(\right.$ Bjergbakke et al., 1984). But, up to $\mathrm{W} / \mathrm{C}=0.4$, the $\mathrm{H}_{2}$ yield is much lower in CAC. Such difference in terms of $\mathrm{H}_{2}$ production between Portland and CAC cement could be partially explained by the nature of the hydrates present in these cements: Portland cement paste is mainly composed of C-S-H and portlandite $\mathrm{Ca}(\mathrm{OH})_{2}$, whereas CAC cement paste contains mainly $\mathrm{AH}_{3}$ and $\mathrm{C}_{3} \mathrm{AH}_{6}$. The determination of the $\mathrm{H}_{2}$ radiolytic yields of $\mathrm{AH}_{3}$ and $\mathrm{C}_{3} \mathrm{AH}_{6}$ pure hydrates under gamma irradiation, measured under comparable conditions, is lacking in the literature. In order to highlight the role of the hydrates in the $\mathrm{H}_{2}$ production of $\mathrm{CAC}$ cement, $\mathrm{AH}_{3}$ and $\mathrm{C}_{3} \mathrm{AH}_{6}$ were studied separately, and also monocarboaluminate as an hydrated (although minor) phase.

\subsection{3. $H_{2}$ production of hydrates: $A_{3} H_{3} C_{3} A H_{6}$ and monocarboaluminate}

The hydrogen productions of $\mathrm{AH}_{3}, \mathrm{C}_{3} \mathrm{AH}_{6}$ and monocarboaluminate irradiated under gamma irradiation were measured. $\mathrm{G}\left(\mathrm{H}_{2}\right)$ and $\mathrm{G}\left(\mathrm{H}_{2}\right)_{\text {normalized }}$ values are reported in Table 4.

To the best of our knowledge, only two studies reported $\mathrm{G}\left(\mathrm{H}_{2}\right)$ values for $\mathrm{AH}_{3}$ and there is no available data concerning $\mathrm{C}_{3} \mathrm{AH}_{6}$ and monocarboaluminate. Westbrook et al. reported the hydrogen production of dry $\mathrm{AH}_{3}$ (gibbsite heated up to $60{ }^{\circ} \mathrm{C}$ during 24 hours) under air: the $\mathrm{H}_{2}$ yield was found almost equal to zero (Westbrook et al., 2015). Results were also reported by Kaddissy et al. on dry $\mathrm{AH}_{3}$ (gibbsite heated up to $130{ }^{\circ} \mathrm{C}$ for $4 \mathrm{~h}$ under high vacuum conditions $\left.\left(10^{-4} \mathrm{mbar}\right)\right)$ under electron irradiation ( $10 \mathrm{MeV}$ pulsed electron beam, $28 \mathrm{~Gy} /$ pulse of $10 \mathrm{~ns}$ at $5 \mathrm{~Hz}$, dose $=120 \mathrm{kGy}$ ) which are slightly higher $\left(0.021 \pm 0.005 \times 10^{-7}\right)$ than those presented here (Kaddissy et al., 2017). In all cases, it is difficult to compare our results with the literature data due to the heterogeneity of the experimental conditions (storage and irradiation). Indeed, differences between $\mathrm{G}\left(\mathrm{H}_{2}\right)$ values depending on the source of irradiation have already been observed (LaVerne and Tandon, 2005).

The normalized $\mathrm{H}_{2}$ yields of $\mathrm{AH}_{3}$ and $\mathrm{C}_{3} \mathrm{AH}_{6}$ measured here are one order of magnitude lower than the radiolytic yield of water at pH 13 after (Bjergbakke et al., 1984). They are also lower than the ones reported for the two main hydrates of Portland cement: C-S-H (ranging from $(2.13 \pm 0.21)$ to $(3.23 \pm 0.32) \times 10^{-7} \mathrm{~mol} / \mathrm{J}$ (Yin et al., 2019) and portlandite $\left((0.19 \pm 0.02) \times 10^{-7} \mathrm{~mol} / \mathrm{J}\right.$ (Acher et al., 2017a)). The normalized $\mathrm{H}_{2}$ yields of $\mathrm{AH}_{3}$ and $\mathrm{C}_{3} \mathrm{AH}_{6}$ are also lower than the ones determined for $\mathrm{K}$ struvite (main hydrate of MPC) and ettringite (major hydrated phase in CSA) (Table 4). Concerning monocarboaluminate, its normalized $\mathrm{H}_{2}$ yield is almost equal to the one of water (Table 4). These 
results clearly tell us that (1) hydroxyl groups in $\mathrm{AH}_{3}$ and $\mathrm{C}_{3} \mathrm{AH}_{6}$ produce less hydrogen under irradiation than free water, and that (2) $\mathrm{AH}_{3}$ and $\mathrm{C}_{3} \mathrm{AH}_{6}$ produce less hydrogen than the major constitutive hydrates of Portland, MPC and CSA cements.

So far, it is difficult to explain those findings. Both hydroxyl groups and water molecules can contribute to the $\mathrm{H}_{2}$ radiolytic yield depending on their bonding in the crystal structure and de facto on the nature of the atoms they are bound to. Our (heuristic) approach consists in accumulating data on different systems with different crystal structures going from simple to more complex ones, and to vary the irradiation conditions. In this context, the crystal structures of the different hydrates studied are sketched on Fig. 10 with clearly specified the presence of $\mathrm{OH}$ groups and/or water in the structure. The different normalized $\mathrm{H}_{2}$ radiolytic yields of the major hydrates of CAC, MPC, CSA and Portland cements are also reported in Fig. 11. Only hydroxyl groups enter in the structures of portlandite, gibbsite and katoite. We also note that portlandite $\left(\mathrm{Ca}(\mathrm{OH})_{2}\right)$ and gibbsite $\mathrm{AH}_{3}\left(\mathrm{Al}\left(\mathrm{OH}_{3}\right)\right)$, both exhibit rather close layered structures (Chaix-Pluchery et al., 1987; Desgranges et al., 1996; Megaw, 1934; Saalfeld and Wedde, 1974). So once remarked that irradiated portlandite exhibits an $\mathrm{H}_{2}$ yield more than ten times higher than the one of $\mathrm{C}_{3} \mathrm{AH}_{6}$ and almost five times higher than the one of $\mathrm{AH}_{3}$, this means that the nature of the cation could be responsible of such a difference. If we consider monocarboaluminate, ettringite and K-struvite hydrates, that all contain molecular water, it seems that the presence of molecular water favors the production of dihydrogen, resulting in a normalized $\mathrm{G}\left(\mathrm{H}_{2}\right)$ similar or close to the one of free water for the three compounds. In the case of K-struvite, water is engaged in the $\mathrm{Mg}$ octahedra so maybe it is the reason for a lower value of $\mathrm{G}\left(\mathrm{H}_{2}\right)_{\text {normalized }}$ compared to the one of free water. On the contrary, the normalized yield of ettringite is higher than the one of free water, compatible with the fact that water in ettringite is more sensitive to gamma radiation than free water (Table 4). This may be put in parallel with the columnar structure of ettringite where molecular water is located in channels. Finally, one could notice the especially high normalized $\mathrm{G}\left(\mathrm{H}_{2}\right)$ value of $\mathrm{C}-\mathrm{S}-\mathrm{H}$ compared to the ones of all others mentioned hydrates and water.

\subsubsection{Calculation of $\mathrm{H}_{2}$ production in CAC pastes from hydrates and free water}

In this section, it is proposed to estimate the $\mathrm{H}_{2}$ yields of CAC pastes based on their compositions as determined by XRD and their amount of free water determined according to the critical W/C ratio calculated in section 3.1.1 (an average value of 0.32 is considered here). While disregarding all microstructural and wetting aspects, a simple assumption is that the $\mathrm{H}_{2}$ yield of a paste is the sum of the yield of the hydrates and that of free (pore) water, according to:

$$
G\left(H_{2}\right)_{\text {cement paste }}=\sum\left(X_{\text {hydrate }} \times G\left(H_{2}\right)_{\text {hydrate }}\right)+X_{F W} \times G\left(H_{2}\right)_{F W}
$$


Where $X_{\text {hydrate }}$ and $X_{\mathrm{FW}}$ are the mass fraction of hydrate and free water respectively in the material, $\mathrm{G}\left(\mathrm{H}_{2}\right)_{\text {hydrate }}$ the yield of hydrate as determined in Table $4^{2}$ and $\mathrm{G}\left(\mathrm{H}_{2}\right)_{\mathrm{FW}}$ the yield of water at $\mathrm{pH} 13$ $\left(=4.4 .10^{-8} \mathrm{~mol} / \mathrm{J}\right)$. For W/C below the critical value of 0.32 , the mass fraction of free water is considered null. Above this value, assuming that no desiccation occurs during conservation and irradiation, it is equal to:

$$
X_{F W}=\frac{\frac{W}{C}-0.32}{\frac{W}{C}+1}
$$

Considering hydrates, the mass fraction is the one determined by XRD (Table 2) corrected by the amount of free water in the paste. Indeed, the percentage determined by XRD (Rietveld) refers to the solid phase only. The correction is given in Table 5. The estimated $\mathrm{H}_{2}$ yields of the Ciment Fondu pastes are reported in Fig. 12 and compared to experimental data. Despite simplified assumptions, the estimation fits well experimental data except for $\mathrm{W} / \mathrm{C}=0.3$ where the yield is underestimated by a factor of 2 . This could be explained first, by the low amount of monocarboaluminate (1 wt.\%) in this sample and secondly, by the calculation of the critical W/C (considered equal to 0.32). Considering the contribution of hydrates $\left[\sum\left(X_{\text {hydrate }} \times G\left(H_{2}\right)_{\text {hydrate }}\right)\right]$ and the contribution of free water $\left[X_{F W} \times\right.$ $\left.G\left(H_{2}\right)_{F W}\right]$ as presented in Fig. 12, it is clear that the production of $\mathrm{H}_{2}$ comes mainly from free (pore) water for W/C above 0.4. One should minimize the W/C of CAC-based materials if $\mathrm{H}_{2}$ production is a concern.

\section{Conclusion}

In the present paper, we report the results of the radiolytic behavior under gamma irradiation with a ${ }^{60} \mathrm{Co}$ source of a Calcium Aluminate Cement (CAC, Ciment Fondu) and of its major stable constitutive hydrates, katoite $\mathrm{C}_{3} \mathrm{AH}_{6}$ and gibbsite $\mathrm{AH}_{3}$. The amount of dihydrogen was measured for various Ciment Fondu pastes with W/C varying from 0.2 to 0.6 and for the synthetic hydrates.

A first result is that CAC cement is less radiolysable than other cements (Portland, CSA and MPC). Secondly, the $\mathrm{H}_{2}$ production is very low below the so-called critical water to cement ratio ( 0.32) and increases above. It is shown that the dihydrogen production is driven by the hydrates below the critical water to cement ratio and driven by free water above. In other words, the W/C ratio should be adjusted to a minimum value in the region of its so-called critical value $(\sim 0.32)$ to limit the radiolytic $\mathrm{H}_{2}$ production in CAC pastes.

Thus, the status of water (free water or water chemically bound in the hydrates) has a significant influence on the $\mathrm{H}_{2}$ yields in CAC cement pastes, which is not the case for Portland cement paste

\footnotetext{
${ }^{2}$ The radiolytic yields of hydrates are the values measured on synthetic "pure" compounds, without considering the presence of iron or any other impurities in solid solutions.
} 
where the normalized $\mathrm{G}\left(\mathrm{H}_{2}\right)$ remains constant at a high level over the whole W/C range. So, the $\mathrm{H}_{2}$ yield of $\mathrm{CAC}$ is lower since both $\mathrm{AH}_{3}$ and $\mathrm{C}_{3} \mathrm{AH}_{6}$ hydrates produce less $\mathrm{H}_{2}$ than hydrates of Portland cement (C-S-H, portlandite, ettringite) and of some MPC cements (K-struvite).

Moreover, all the above-mentioned hydrates behave differently under irradiation and it appears that hydrates containing only hydroxyl groups produce less $\mathrm{H}_{2}$ under present gamma irradiation conditions than those with molecular water. However, it is found that the $\mathrm{H}_{2}$ production varies significantly depending on the hydrates, even for those containing only hydroxyl groups, suggesting that other parameters such as porosity, microstructure, impurities, or simply the nature of the cation could also impact the hydrogen production.

In addition, the crystal structures of $\mathrm{AH}_{3}$ and $\mathrm{C}_{3} \mathrm{AH}_{6}$ are preserved up to $3 \mathrm{GGy}$ under electron irradiation. Further experiments with alpha emitters remain to be done in order to assess the potential of CAC for the conditioning of nuclear wastes.

\section{Acknowledgments}

The authors would like to thank the EMIR\&A French accelerator network for radiation beam time. Marie-Noëlle de Noirfontaine and David Chartier are very grateful to Stephane Berger (Imerys) for fruitful discussion about CAC cement. 


\section{References}

Acher, L., Chartier, D., Dannoux-Papin, A., Haas, J., Courtial, M., De Noirfontaine, M.-N., Dunstetter, F., Gorse-Pomonti, D., Tusseau-Nenez, S., 2017a. Radioactive waste conditioning: the choice of the cement matrix versus irradiation, 37th Cement and Concrete Science Conference, London, United Kingdom.

Acher, L., 2017b. Etude du comportement sous irradiation $\gamma$ et électronique de matrices cimentaires et de leurs hydrates constitutifs. Université Paris-Saclay, Palaiseau, France.

ASTM, I., ISO-ASTM 51261 Guide for selection and calibration of dosimetry systems for radiation processing.

Barnes, P., Colston, S.L., Jupe, A.C., Jacques, S.D.M., Attfield, M., Pisula, R., Morgan, S., Hall, C., Livesey, P., Lunt, S., 2002. Structure and Performance of Cements, Second Edition ed. Spon Press, London \& New York.

Bensted, J., Varma, S.P., 1974. Some applications of infrared and Raman spectroscopy in cement chemistry. Part 3-hydration of Portland cement and its constituents. Cement Technology 5, 440-450.

Berger, M.J., 1992. ESTAR, PSTAR, and ASTAR: Computer programs for calculating stoppingpower and range tables for electrons, protons, and helium ions.

Bibler, N.E., 1980. Radiolytic gas generation in concrete made with incinerator ash containing transuranium nuclides. Scientific Basis for Nuclear Waste Management 2, 585-592.

Bjergbakke, E., Sehested, K., Rasmussen, O.L., Christensen, H., 1984. Input files for computer simulation of water radiolysis.

Bouniol, P., 2010. The influence of iron on water radiolysis in cement-based materials. Journal of Nuclear Materials.

Bouniol, P., Bjergbakke, E., 2008. A comprehensive model to describe radiolytic processes in cement medium. Journal of Nuclear Materials 372, 1-15.

Bouniol, P., Guillot, W., Dauvois, V., Dridi, W., Le Caër, S., 2018. Original behavior of pore water radiolysis in cement-based materials containing sulfide: coupling between experiments and simulations. Radiation Physics and Chemistry 150, 172-181.

Bouniol, P., Muzeau, B., Dauvois, V., 2013. Experimental evidence of the influence of iron on pore water radiolysis in cement-based materials. Journal of Nuclear Materials 437, 208-215.

Brown, J.F., Clark, D., Elliott, W.W., 1953. 13. The thermal decomposition of the alumina trihydrate, gibbsite. Journal of the Chemical Society (Resumed), 84-88.

Bykov, G.L., Ershov, V.A., Ershov, B.G., 2020. Radiolysis of the magnesium phosphate cement on $\gamma$ irradiation. Construction and Building Materials 252, 119156.

Carlson, E.T., Berman, H.A., 1960. Some observations on the calcium aluminate carbonate hydrates. Journal of Research of the National Bureau of Standards 64A, 333-341.

Cau-Dit-Coumes, C., Lambertin, D., Lahalle, H., Antonucci, P., Cannes, C., Delpech, S., 2014. Selection of a mineral binder with potentialities for the stabilization/solidification of aluminum metal. Journal of Nuclear Materials 453, 31-40. 
Chaix-Pluchery, O., Pannetier, J., Bouillot, J., Niepce, J.C., 1987. Structural prereactional transformations in $\mathrm{Ca}(\mathrm{OH})_{2}$. Journal of Solid State Chemistry 67, 225-234.

Chartier, D., Sanchez-Canet, J., Antonucci, P., Esnouf, S., Renault, J.-P., Farcy, O., Lambertin, D., Parraud, S., Lamotte, H., Cau Dit Coumes, C., 2020. Behaviour of magnesium phosphate cementbased materials under gamma and alpha irradiation. Journal of Nuclear Materials 541, 152411.

Chartier, D., Sanchez-Canet, J., Bessette, L., Esnouf, S., Renault, J.-P., 2018. Influence of formulation parameters of cement based materials towards gas production under gamma irradiation. Journal of Nuclear Materials 511, 183-190.

Cheary, R.W., Coelho, A.A., 1992. A fundamental parameters approach to X-ray line-profile fitting. Journal of Applied Crystallography 25, 109-121.

Christensen, H., Bjergbakke, E., 1984. Radiolysis of concrete. Journal of Industrial Irradiation Technology 2, 321-344.

Colville, A.A., Geller, S., 1971. The crystal structure of brownmillerite, $\mathrm{Ca}_{2} \mathrm{FeAlO}_{5}$. Acta Crystallographica B 27, 2311-2315.

Craeye, B., De Schutter, G., Vuye, C., Gerardy, I., 2015. Cement-waste interactions: hardening selfcompacting mortar exposed to gamma radiation. Progress in Nuclear Energy 83, 212-219.

de Noirfontaine, M.-N., Acher, L., Courtial, M., Dunstetter, F., Gorse - Pomonti, D., 2018. An X-ray powder diffraction study of damage produced in $\mathrm{Ca}(\mathrm{OH})_{2}$ and $\mathrm{Mg}(\mathrm{OH})_{2}$ by electron irradiation using the 2.5 MeV SIRIUS accelerator. Journal of Nuclear Materials 509, 78-93.

de Noirfontaine, M.-N., Garcia-Caurel, E., Funes-Hernando, D., Courtial, M., Tusseau-Nenez, S., Cavani, O., Jdaini, J., Cau-Dit-Coumes, C., Dunstetter, F., Gorse - Pomonti, D., 2021. Amorphization of a proposed sorbent of strontium, brushite, $\mathrm{CaHPO}_{4} \cdot 2 \mathrm{H}_{2} \mathrm{O}$, studied by X-ray diffraction and Raman spectroscopy. Journal of Nuclear Materials 545, 152751.

Desgranges, L., Calvarin, G., Chevrier, G., 1996. Interlayer Interactions in $M(\mathrm{OH})_{2}$ : A Neutron Diffraction Study of $\mathrm{Mg}(\mathrm{OH})_{2}$. Acta Crystallographica Section B: Structural Science 52, 82-86.

Dilnesa, B.Z., Lothenbach, B., Renaudin, G., Wichser, A., Kulik, D., 2014. Synthesis and characterization of hydrogarnet $\mathrm{Ca}_{3}\left(\mathrm{Al}_{x} \mathrm{Fe}_{1-x}\right)_{2}\left(\mathrm{SiO}_{4}\right)_{y}(\mathrm{OH})_{4(3-\mathrm{y})}$. Cement and Concrete Research 59, 96-111.

Dollase, W., 1986. Correction of intensities for preferred orientation in powder diffractometry: application of the March model. Journal of Applied Crystallography 19, 267-272.

Dvoriankina, G., Pinsker, Z., 1960. Electron diffraction pattern study of $\mathrm{Fe}_{3} \mathrm{O}_{4}$. Doklady Akademii Nauk SSSR 132, 110-113.

El Omar, A.K., Baldacchino, G., Monnet, I., Bouniol, P., 2015. Revisited water radiolysis at elevated pH by accounting $\mathrm{O}_{3}{ }^{-}$kinetics at low and high LET. RCS Advances 5, 89244-89253.

François, M., Renaudin, G., Evrard, O., 1998. A cementitious compound with composition 3CaO. $\mathrm{Al}_{2} \mathrm{O}_{3}$. $\mathrm{CaCO}_{3} .11 \mathrm{H}_{2} \mathrm{O}$. Acta Crystallographica Section C: Crystal Structure Communications 54, 1214-1217.

Gabrovšek, R., Vuk, T., Kaučič, V., 2008. The preparation and thermal behavior of calcium monocarboaluminate. Acta Chimica Slovenica 55, 942-950. 
Gemmi, M., Merlini, M., Cruciani, G., Artioli, G., 2007. Non-ideality and defectivity of the akermanite-gehlenite solid solution: an X-ray diffraction and TEM study. American Mineralogist 92, 1685-1694.

Gloter, A., Ingrin, J., Bouchet, D., Scrivener, K., Colliex, C., 2000. TEM evidence of perovskitebrownmillerite coexistence in the $\mathrm{Ca}\left(\mathrm{Al}_{\mathrm{x}} \mathrm{Fe}_{1-\mathrm{x}}\right) \mathrm{O}_{2.5}$ system with minor amounts of titanium and silicon. Physics and Chemistry of Minerals 27, 504-513.

Guirado, F., Gali, S., 2006. Quantitative Rietveld analysis of CAC clinker phases using synchrotron radiation. Cement and Concrete Research 36, 2021-2032.

Hanic, F., Handlovic, M., Kapralik, I., 1980. The structure of a quaternary phase $\mathrm{Ca}_{20} \mathrm{Al}_{32-2 v} \mathrm{Mg}_{v} \mathrm{Si}_{\mathrm{v}} \mathrm{O}_{68}$. Acta Crystallographica B 36, 2863-2869.

Harwell, http://www.harwell-dosimeters.co.uk/perspex/.

Hewlett, P.C., Liska, M., 2019. Lea's Chemistry of Cement and Concrete, Fifth Edition ed, pp. 537584.

Hörkner, W., Müller-Buschbaum, H.K., 1976. Zur Kristallstruktur von $\mathrm{CaAl}_{2} \mathrm{O}_{4}$. Journal of Inorganic and Nuclear Chemistry 38, 983-984.

Kaddissy, J.A., Esnouf, S., Durand, D., Saffre, D., Foy, E., Renault, J.-P., 2017. Radiolytic events in nanostructured aluminum hydroxides. The Journal of Physical Chemistry C 121, 6365-6373.

Kearney, S.A., McLuckie, B., Webb, K., Orr, R., Vatter, I.A., Corkhill, C.L., Hayes, M., Angus, M.J., Provis, J.L., 2020. Effects of plutonium dioxide encapsulation on the physico-chemical development of Portland cement blended grouts. Journal of Nuclear Materials 530, 151960.

Kloprogge, J.T., Ruan, H.D., Frost, R.L., 2002. Thermal decomposition of bauxite minerals: infrared emission spectroscopy of gibbsite, boehmite and diaspore. Journal of Materials Science 37, 11211129.

Kyono, A., Arora, S., 2019. Crystal structure change in grossular-Si-free katoite solid solution: oxygen position splitting in katoite. Journal of Mineralogical and Petrological Sciences 114, 189-200.

Lager, G.A., Von Dreele, R.B., 1996. Neutron powder diffraction study of hydrogarnet to 9.0 GPa. American Mineralogist 81, 1097-1104.

LaVerne, J.A., Tandon, L., 2005. $\mathrm{H}_{2}$ and $\mathrm{Cl}_{2}$ production in the radiolysis of calcium and magnesium chlorides and hydroxides. The Journal of Physical Chemistry A 109, 2861-2865.

Le Saout, G., Idir, R., Roux, J.-C., 2019. Characterisation of perovskites in a Calcium Sulfo Aluminate cement, International Congress on Applied Mineralogy. Springer, pp. 339-343.

Lodding, E., 1969. The gibbsite dehydroxylation fork. Thermal Analysis 2, 1239-1250.

Majumdar, A.J., Roy, R., 1956. The system $\mathrm{CaO}-\mathrm{Al}_{2} \mathrm{O}_{3}-\mathrm{H}_{2} \mathrm{O}$. Journal of the American Ceramic Society 39, 434-442.

Matschei, T., 2007. Thermodynamics of cement hydration. University of Aberdeen, Aberdeen, United Kingdom.

Megaw, H.D., 1934. The Crystal Structure of Hydrargillite, $\mathrm{Al}(\mathrm{OH})_{3}$. Zeitschrift für KristallographieCrystalline Materials 87, 185-205. 
Möckel, H.J., Köster, R.H., 1982. Gas formation during the gamma radiolysis of cemented low-and intermediate-level waste products. Nuclear Technology 59, 494-497.

Mumme, W.G., Hill, R.J., Bushnell-Wye, G., Segnit, E.R., 1995. Rietveld crystal structure refinements, crystal chemistry and calculated powder diffraction data for the polymorphs of dicalcium silicate and related phases. Neues Jahrbuch für Mineralogie Abhandlungen 169, 35-68.

Offermann, P., 1988. Calculation of the radiolytic gas production in cemented waste, MRS Proceedings. Cambridge Univ Press, p. 461.

Ollivier, J.P., Vichot, A., 2008. La durabilité des bétons, 2ème Edition. Presses de l'Ecole Nationale des Ponts et Chaussées, pp. 767-823.

Passaglia, E., Rinaldi, R., 1984. Katoite, a new member of the $\mathrm{Ca}_{3} \mathrm{Al}_{2}\left(\mathrm{SiO}_{4}\right)_{3}-\mathrm{Ca}_{3} \mathrm{Al}_{2}(\mathrm{OH})_{12}$ series and a new nomenclature for the hydrogrossular group of minerals. Bulletin de Minéralogie 107, 605-618.

Pellenq, R.J.-M., Kushima, A., Shahsavari, R., Van Vliet, K.J., Buehler, M.J., Yip, S., Ulm, F.-J., 2009. A realistic molecular model of cement hydrates. Proceedings of the National Academy of Sciences 106, 16102-16107.

Powers, T.C., Brownyard, T.L., 1946. Studies of the physical properties of hardened Portland cement paste, Journal Proceedings, pp. 101-132.

Ramachandran, V.S., Zhang, C.-M., 1986. Thermal analysis of the $3 \mathrm{CaO}^{-} \mathrm{Al}_{2} \mathrm{O}_{3}-\mathrm{CaSO}_{4} \cdot 2 \mathrm{H}_{2} \mathrm{O}-\mathrm{CaCO}_{3}-$ $\mathrm{H}_{2} \mathrm{O}$ system. Thermochimica Acta 106, 273-282.

Rickerby, J.A., 2015. Characterisation of hardened cements incorporating simulant intermediate level waste University of Leeds, Leeds, UK.

Rietveld, H., 1969. A profile refinement method for nuclear and magnetic structures. Journal of applied Crystallography 2, 65-71.

Rinaldi, R., Sacerdoti, M., Passaglia, E., 1990. Stràtlingite: crystal structure, chemistry, and a reexamination of its polytype vertumnite. European Journal of Mineralogy 2, 841-849.

Rodriguez-Carvajal, J., Vallet-Regi, M., J.M., G.C., 1989. Perovskite threefold superlattices: a structure determination of the $\mathrm{A}_{3} \mathrm{M}_{3} \mathrm{O}_{8}$ phase. Materials Research Bulletin 24, 423-430.

Saalfeld, H., Depmeier, W., 1972. Silicon-free compounds with sodalite structure. Kristall und Technik 7, 229-233.

Saalfeld, H., Wedde, M., 1974. Refinement of the crystal structure of gibbsite, $\mathrm{Al}(\mathrm{OH})_{3}$. Zeitschrift für Kristallographie 139, 129-135.

Sakakura, T., Tanaka, K., Takenaka, Y., Matsuishi, S., Hosonod, H., Kishimoto, S., 2011. Determination of the local structure of a cage with an oxygen ion in $\mathrm{Ca}_{12} \mathrm{Al}_{14} \mathrm{O}_{33}$. Acta Crystallographica B 67, 193-204.

Scrivener, K.L., Cabiron, J.-L., Letourneux, R., 1999. High-performance concretes from calcium aluminate cements. Cement and Concrete Research 29, 1215-1223.

Soo, P., Milian, M., 2001. The effect of gamma radiation on the strength of Portland cement mortars. Journal of Materials Science Letters 20, 1345-1348.

Taylor, H.F.W., 1997. Cement Chemistry. 2nd edition, Thomas Telford Edition, London. 
Vodak, F., Trtik, K., Sopko, V., Kapickova, O., Demo, P., 2005. Effect of $\gamma$-irradiation on strength of concrete for nuclear-safety structures. Cement and Concrete Research 35, 1447-1451.

Westbrook, M.L., Sindelar, R.L., Fisher, D.L., 2015. Radiolytic hydrogen generation from aluminium oxyhydroxide solids: theory and experiment. Journal of Radioanalytical and Nuclear Chemistry 303, 81-86.

Yamanaka, T., Hirai, N., Komatsu, Y., 2002. Structure change of $\mathrm{Ca}_{1-\mathrm{x}} \mathrm{Sr}_{\mathrm{x}} \mathrm{TiO}_{3}$ perovskite with composition and pressure. American Mineralogist 87, 1183-1189.

Yin, C., Dannoux-Papin, A., Haas, J., Renault, J.-P., 2019. Influence of calcium to silica ratio on $\mathrm{H}_{2}$ gas production in calcium silicate hydrate. Radiation Physics and Chemistry 162, 66-71. 

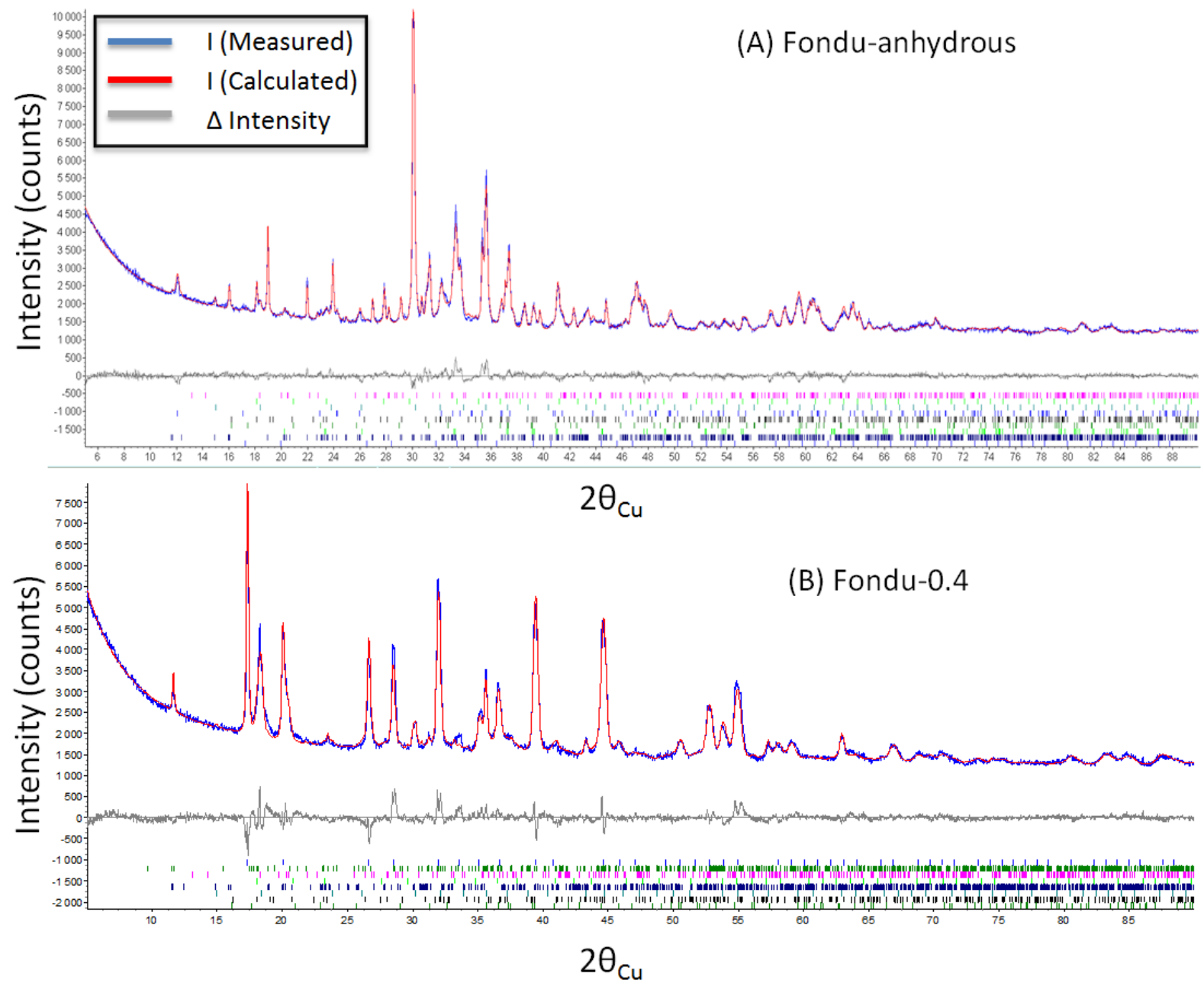

Fig. 1. Rietveld refinement of XRD data of samples (A) Fondu-anhydrous and (B) Fondu- 0.4 $(\mathrm{W} / \mathrm{C}=0.4)$. Are represented: the observed (blue curve) and calculated (red curve) XRD patterns, the difference plot between observed and calculated data, the Bragg reflection markers.

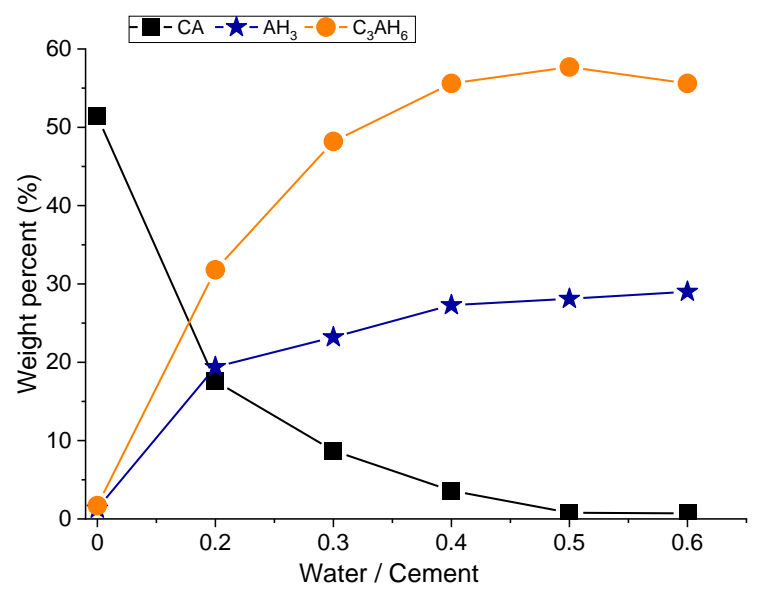

Fig. 2. $\mathrm{CA}, \mathrm{AH}_{3}, \mathrm{C}_{3} \mathrm{AH}_{6}$ and monocarboaluminate weight percents versus $\mathrm{W} / \mathrm{C}$ ratios in $\mathrm{CF}$ cement pastes according to the quantitative phase analysis by Rietveld method 


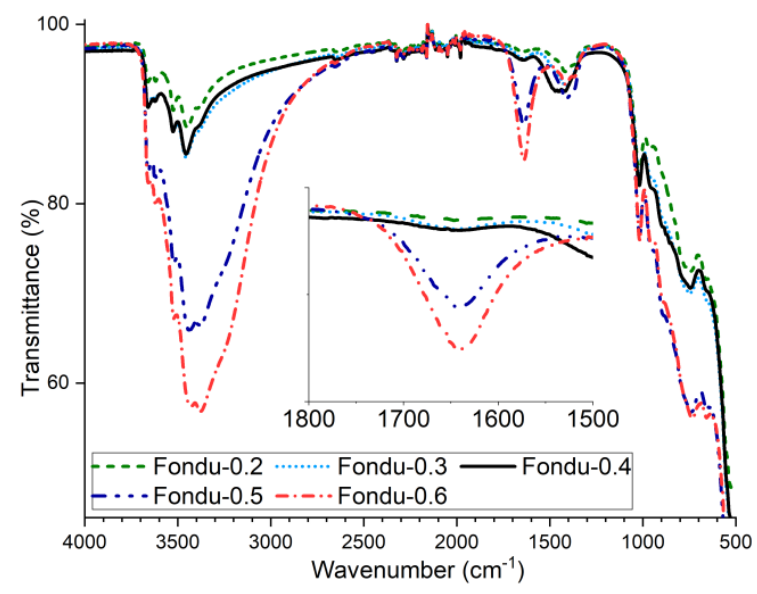

Fig. 3. Infrared spectra of Ciment Fondu pastes obtained at different W/C ratios (from 0.2 to 0.6). Zoom of the band at $1640 \mathrm{~cm}^{-1}$ attributed to the O-H bending vibration of water [Bensted 1974]. The band is much more intense from value of $\mathrm{W} / \mathrm{C}=0.5$.

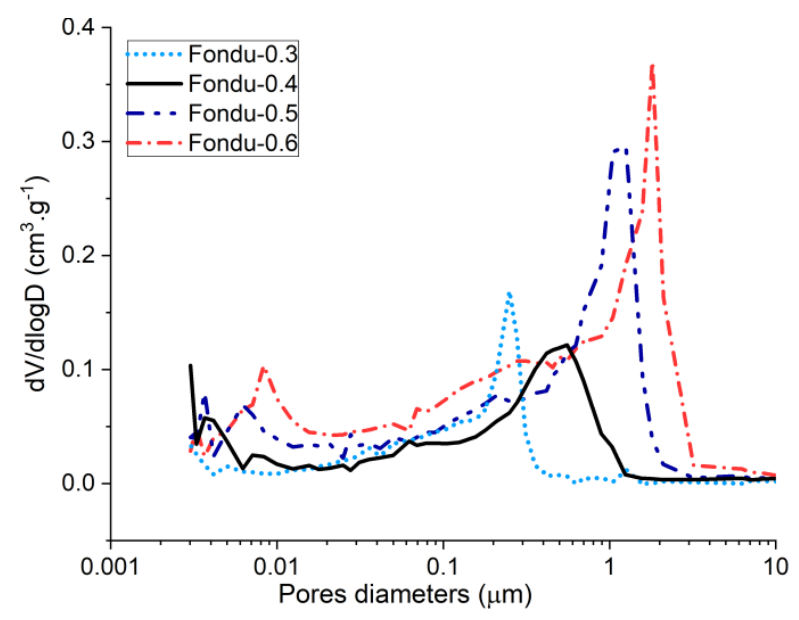

Fig. 4. Pore size distribution of Fondu cement pastes determined by mercury porosimetry at different W/C ratios (from 0.3 to 0.6 ). Note that no data are available for Fondu- 0.2 due to the appearance of cracks inside the material during measurement.

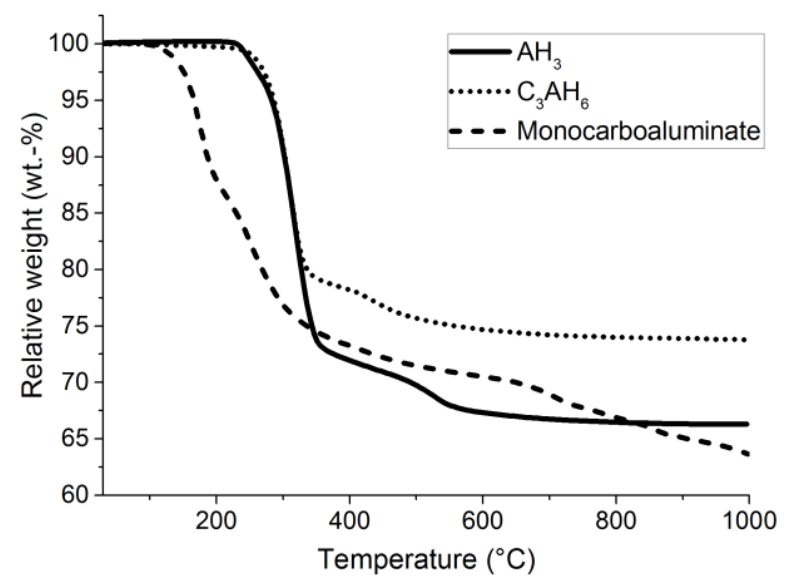

Fig. 5. TG patterns of $\mathrm{AH}_{3}, \mathrm{C}_{3} \mathrm{AH}_{6}$ and monocarboaluminate 


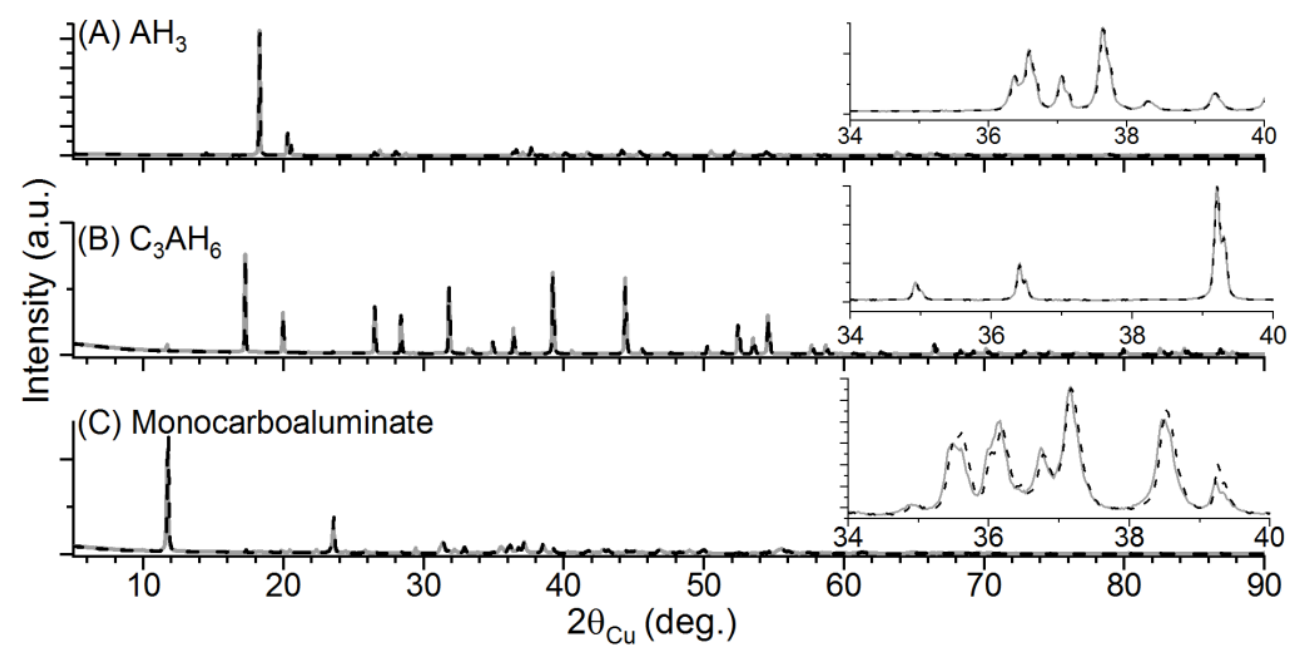

Fig. 6. XRD patterns of (A) $\mathrm{AH}_{3},(\mathrm{~B}) \mathrm{C}_{3} \mathrm{AH}_{6}$ and (C) Monocarboaluminate before (grey curves) and after (black dash curves) $\gamma$-irradiation up to $1 \mathrm{MGy}$ (dose rate: $0.17 \mathrm{~Gy} \cdot \mathrm{s}^{-1}$ ). Patterns are quasi identical, as shown by the magnification of the plot in the range $2 \theta_{\mathrm{Cu}}=34^{\circ}$ to $40^{\circ}$.

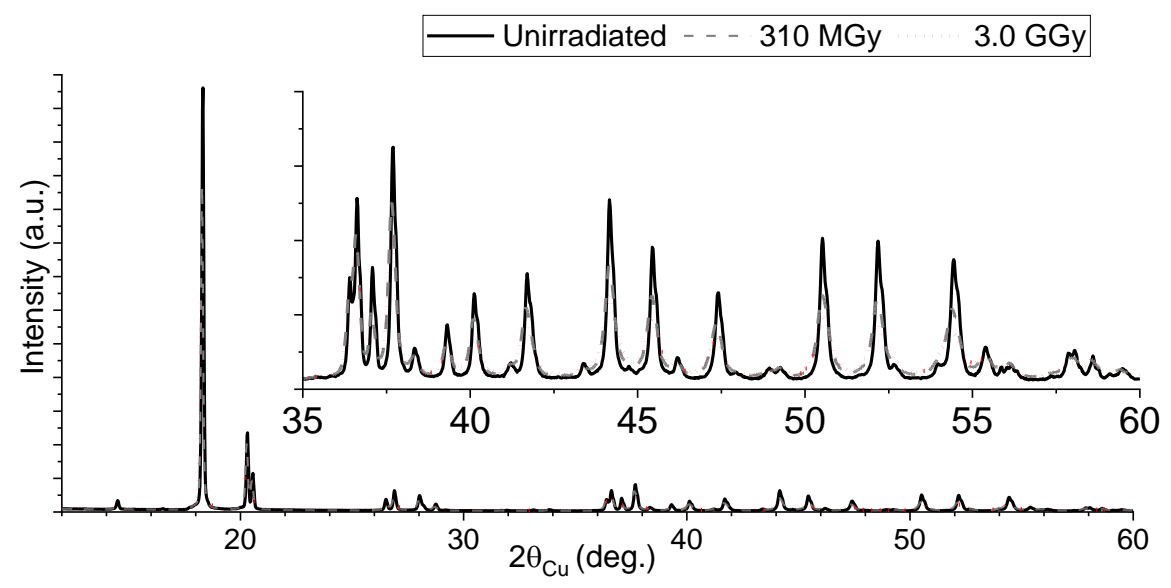

(a) $\mathrm{AH}_{3}$

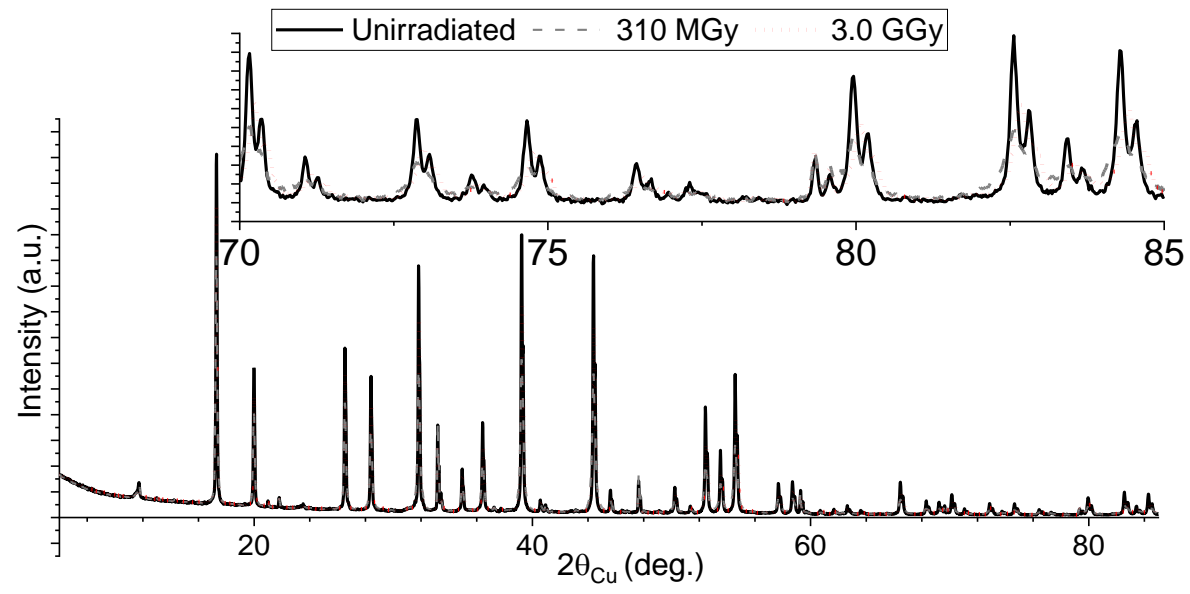

(b) $\mathrm{C}_{3} \mathrm{AH}_{6}$

Fig. 7. XRD patterns of (a) $\mathrm{AH}_{3}$ gibbsite and (b) $\mathrm{C}_{3} \mathrm{AH}_{6}$ katoite following electron irradiation (dose rate: $0.27 \times 10^{5} \mathrm{~Gy} \cdot \mathrm{s}^{-1}$ ) at two doses $310 \mathrm{MGy}$ and $3 \mathrm{GGy}$. No amorphization or any phase transformation is observed, only a shift and broadening of X-Ray diffraction lines. 

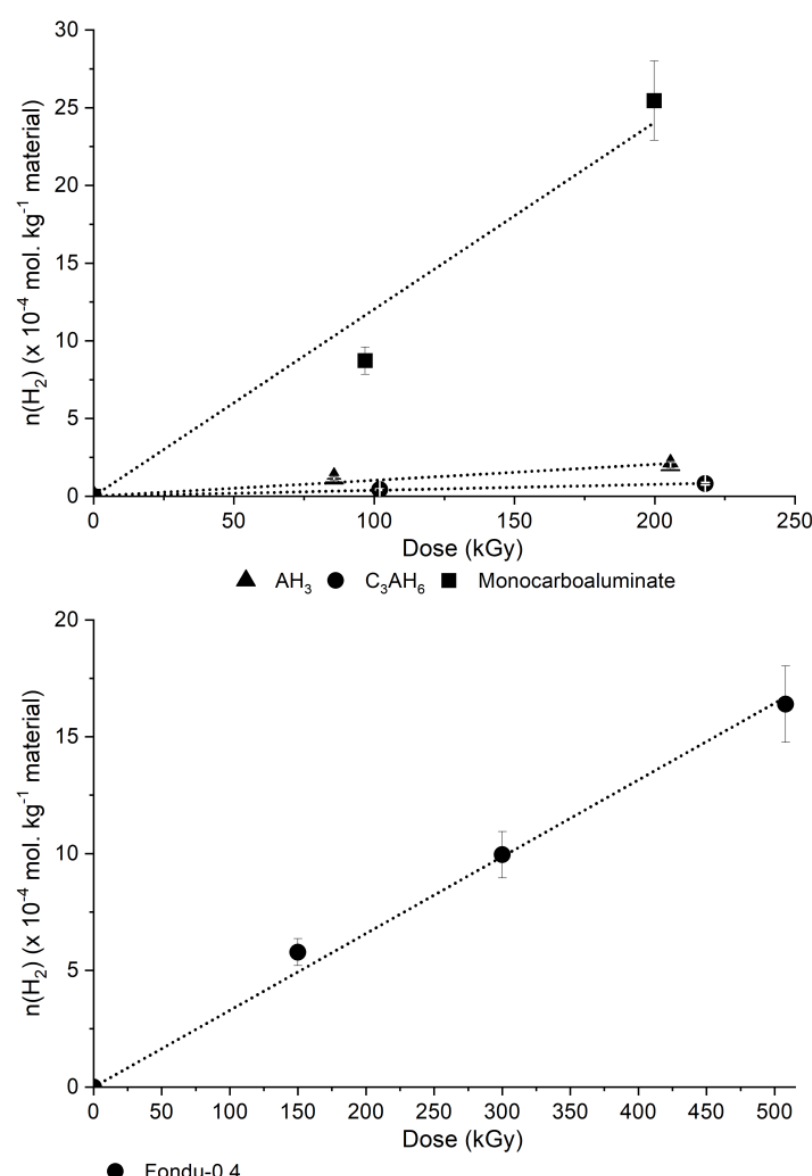

Fig. 8. $\mathrm{H}_{2}$ production as a function of dose under gamma irradiation (top: hydrates / bottom: cement paste with $\mathrm{W} / \mathrm{C}=0.4$ )

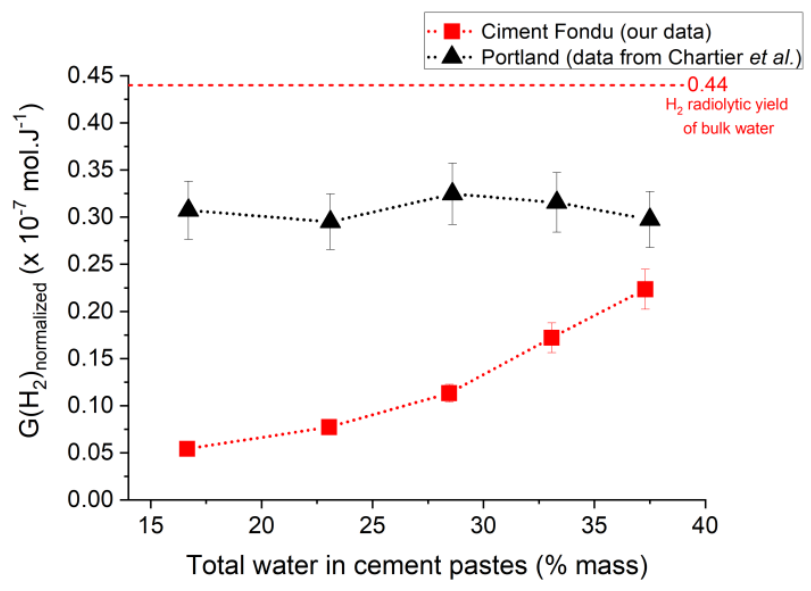

Fig. 9. Normalized $\mathrm{H}_{2}$ radiolytic yields of $\mathrm{CAC}$ cement pastes compared to Portland cement pastes (data from Chartier et al. 2018). The value of $\mathrm{H}_{2}$ radiolytic yield of bulk water is also reported in dashed line. 


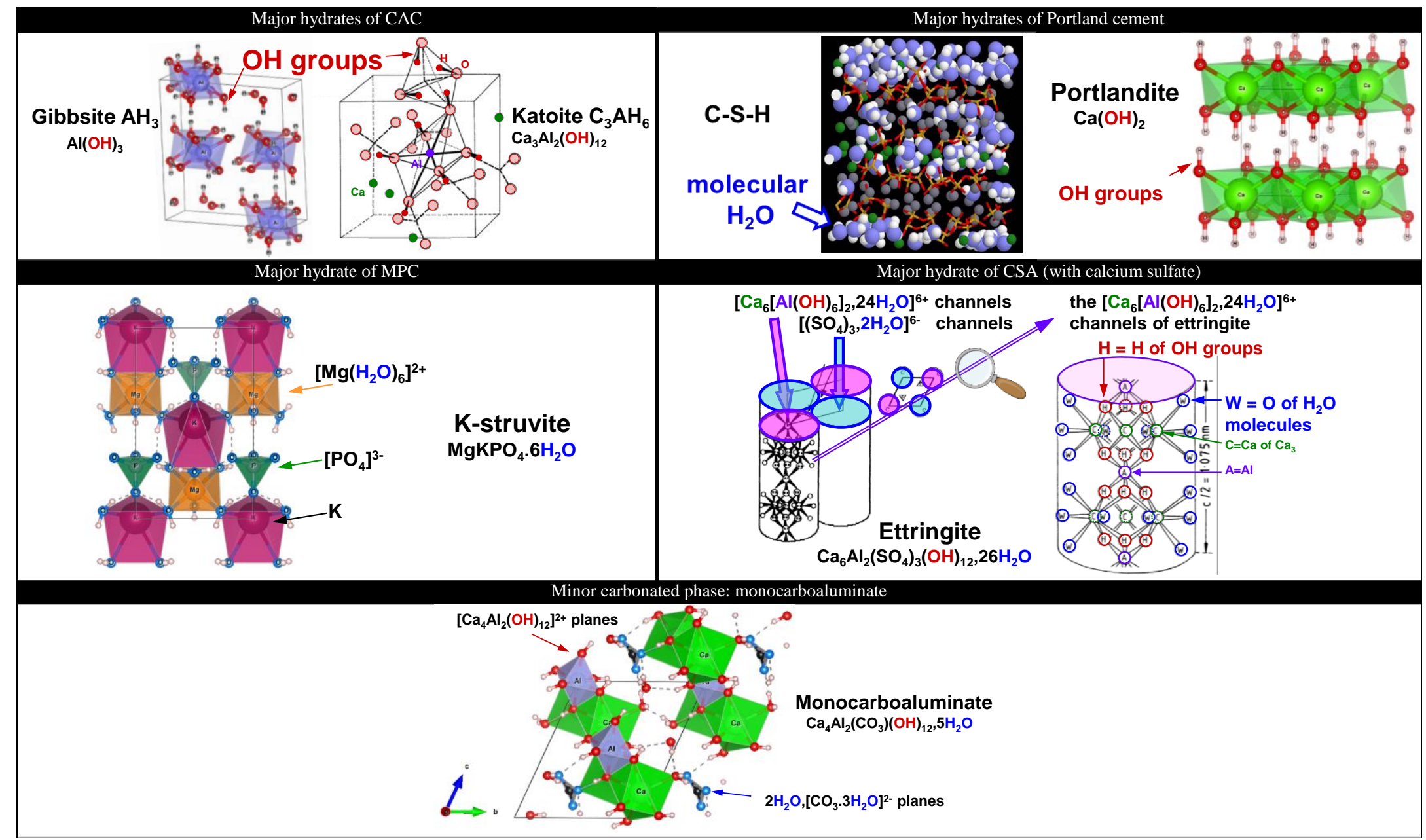

Fig. 10. Structures of major hydrated phases of CAC, Portland, MPC and CSA (with calcium sulfate) cements and of minor carbonated phase: monocarboaluminate. Molecular water $\left(\mathrm{H}_{2} \mathrm{O}\right)$ and hydroxyl water $(\mathrm{OH}$ groups) are highlighted in blue and red respectively. C-S-H structure was adapted from (Pellenq et al. 2009) 


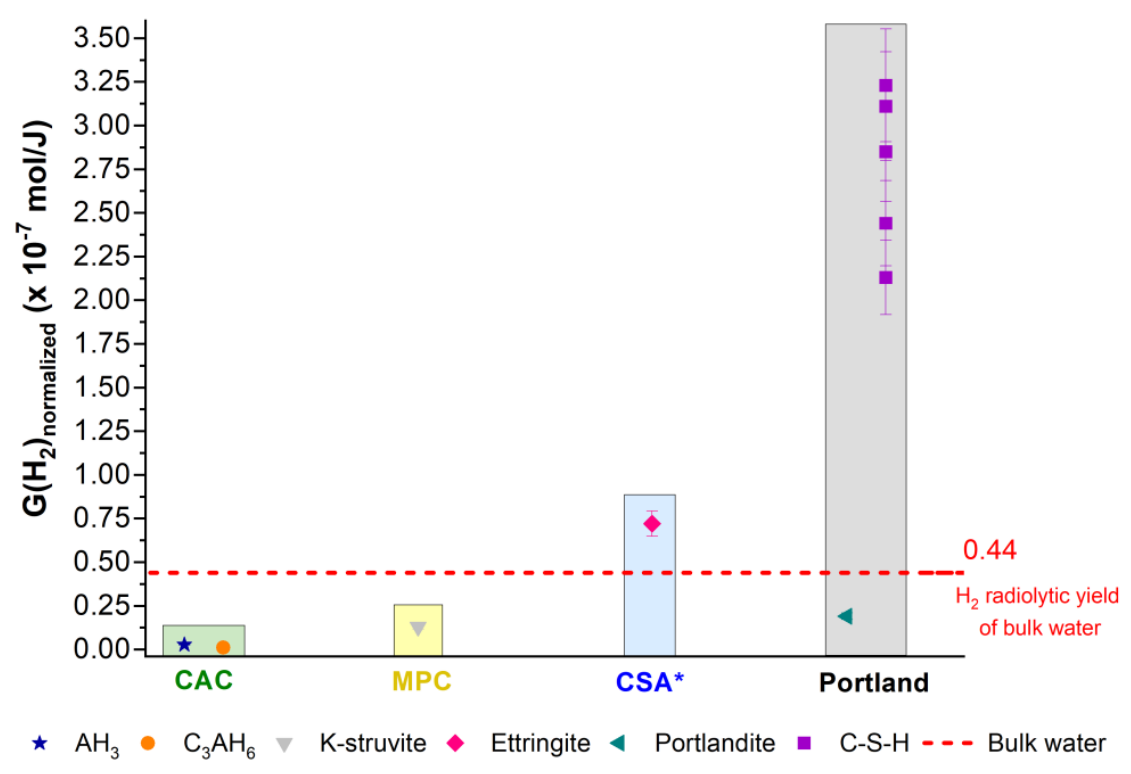

Fig. 11. Normalized $\mathrm{H}_{2}$ radiolytic yields for major hydrates of CAC, MPC, CSA (*with calcium sulfate) and Portland cements (see Table 4 for data). Gamma irradiations were performed under the same conditions. Note that the values of C-S-H, ettringite and K-struvite were determined on samples stored under relative humidity due to the sensitivity of the structure to temperature.

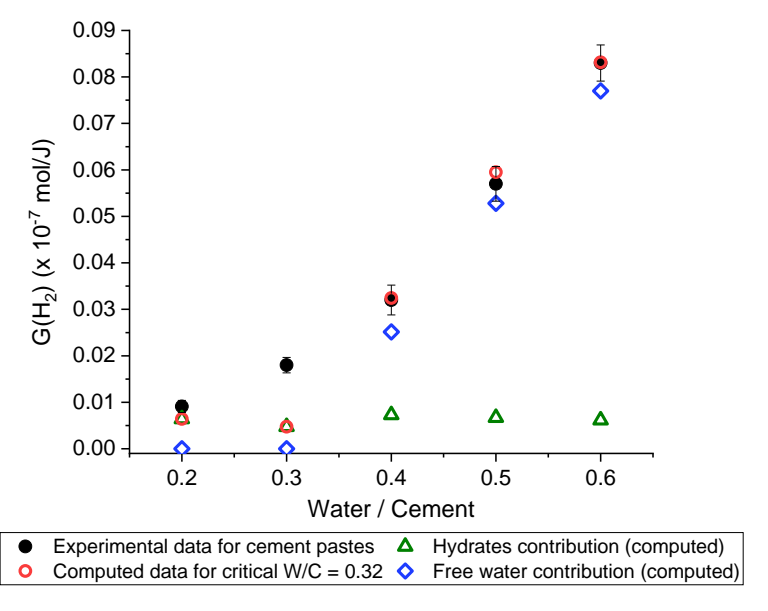

Fig. 12. Comparison between $\mathrm{H}_{2}$ radiolytic yield from experimental data $(\bullet)$ and estimated data (०) based on the equation (see $\S 3.2 .4$ for details): $G\left(H_{2}\right)_{\text {cement paste }}=\sum\left(X_{\text {hydrate }} \times G\left(H_{2}\right)_{\text {hydrate }}\right)+$ $X_{F W} \times G\left(H_{2}\right)_{F W}$ where $X_{\text {hydrate }} \times G\left(H_{2}\right)_{\text {hydrate }}$ and $X_{F W} \times G\left(H_{2}\right)_{F W}$ represent the sum of hydrates $(\Delta)$ and free water $(\diamond)$ contribution respectively 
Table 1. Anhydrous (x) and hydrated (o) phases of Ciment Fondu: structural data, models and Inorganic Crystal Structure Database (ICSD) file number used

\begin{tabular}{|c|c|c|c|c|c|c|c|}
\hline & Phase & Mineral name & Formula & Symmetry & $\begin{array}{l}\text { Space } \\
\text { group }\end{array}$ & Reference & ICSD \\
\hline $\mathrm{x}$ & $\mathrm{CA}$ & Monocalciumaluminate & $\mathrm{CaAl}_{2} \mathrm{O}_{4}$ & Monoclinic & $\mathrm{P} 2{ }_{1} / \mathrm{n}$ & Hörkner 1976 & 260 \\
\hline $\mathrm{x}$ & $\mathrm{C}_{4} \mathrm{AF}$ & Brownmillerite (ferrite) & $\mathrm{Ca}_{2} \mathrm{AlFeO}_{5}$ & Orthorhombic & $\operatorname{Ibm} 2$ & Colville 1971 & 9197 \\
\hline $\mathrm{x}$ & $\beta-\mathrm{C}_{2} \mathrm{~S}$ & Belite & $\mathrm{Ca}_{2} \mathrm{SiO}_{4}$ & Monoclinic & $\mathrm{P} 2{ }_{1} / \mathrm{n}$ & Mumme 1995 & 81096 \\
\hline $\mathrm{x}$ & $\mathrm{C}_{2} \mathrm{AS}$ & Gehlenite & $\mathrm{Ca}_{2} \mathrm{Al}_{2} \mathrm{SiO}_{7}$ & Tetragonal & $\mathrm{P}-42{ }_{1} \mathrm{~m}$ & Gemmi 2007 & 158171 \\
\hline $\mathrm{x}$ & $\mathrm{C}_{12} \mathrm{~A}_{7}$ & Mayenite & $\mathrm{Ca}_{12} \mathrm{Al}_{14} \mathrm{O}_{33}$ & Cubic & $\mathrm{I} 4-3 \mathrm{~d}$ & Sakakura 2011 & 261586 \\
\hline $\mathrm{x}$ & $\mathrm{C}_{4} \mathrm{~A}_{3} \overline{\mathrm{S}}$ & Yeelimite & $\mathrm{Ca}_{4} \mathrm{Al}_{6} \mathrm{SO}_{16}$ & Cubic & $\mathrm{I}-43 \mathrm{~m}$ & Saalfeld 1972 & 9560 \\
\hline $\mathrm{x}$ & $\mathrm{C}_{3} \mathrm{FT}$ & Ferro-Perovskite & $\mathrm{Ca}_{3} \mathrm{TiFe}_{2} \mathrm{O}_{8}$ & Orthorhombic & $\mathrm{Pcm} 2$ & Rodriguez 1989 & 203100 \\
\hline $\mathrm{x}$ & $\mathrm{Fe}_{3} \mathrm{O}_{4}$ & Magnetite (spinel) & $\mathrm{Fe}_{3} \mathrm{O}_{4}$ & Cubic & $\mathrm{Fd}-3 \mathrm{~m}$ & Dvoryankina 1960 & 20596 \\
\hline $\mathrm{x}$ & $\mathrm{CT}$ & Perovskite & $\mathrm{CaTiO}_{3}$ & Orthorhombic & Pnma & Yamanaka 2002 & 94568 \\
\hline $\mathrm{x}$ & Q Phase & Pleochroite & $\mathrm{Ca}_{20} \mathrm{Al}_{26} \mathrm{Mg}_{3} \mathrm{Si}_{3} \mathrm{O}_{68}$ & Orthorhombic & Pmmn:2 & Hanic 1980 & 26353 \\
\hline $\mathrm{o}$ & $\gamma-\mathrm{AH}_{3}$ & Gibbsite & $\mathrm{Al}(\mathrm{OH})_{3}$ & Monoclinic & $\mathrm{P} 21 / \mathrm{n}$ & Saalfeld 1974 & 6162 \\
\hline o & $\mathrm{C}_{3} \mathrm{AH}_{6}$ & Katoite (hydrogarnet) & $\mathrm{Ca}_{3} \mathrm{Al}_{2}(\mathrm{OH})_{12}$ & Cubic & Ia-3d & Lager 1996 & 82404 \\
\hline o & & Monocarboaluminate & $\mathrm{Ca}_{4} \mathrm{Al}_{2}\left(\mathrm{CO}_{3}\right)(\mathrm{OH})_{12 .} .5 \mathrm{H}_{2} \mathrm{O}$ & Triclinic & $\mathrm{P} 1$ & Francois 1998 & 59327 \\
\hline o & $\mathrm{C}_{2} \mathrm{ASH}_{8}$ & Strätlingite & $\mathrm{Ca}_{2} \mathrm{Al}\left((\mathrm{AlSi})_{1.11} \mathrm{O}_{2}\right)(\mathrm{OH})_{12}\left(\mathrm{H}_{2} \mathrm{O}\right)_{2.25}$ & Rhombohedral & $\mathrm{R}-3 \mathrm{~m}$ & Rinaldi 1990 & 69413 \\
\hline
\end{tabular}


Table 2. Quantitative analysis (wt.\%) determined by Rietveld analyses of CF-anhydrous and Fondu-W/C pastes after one year (without considering the fraction of free water). The residues of the refinements $\mathrm{R}_{\mathrm{wp}}$ and $\chi^{2}$ are given in the two last columns.

\begin{tabular}{|c|c|c|c|c|c|c|c|c|c|c|c|c|c|c|c|c|}
\hline Sample & $\mathrm{CA}$ & $\mathrm{C}_{4} \mathrm{AF}$ & $\beta \mathrm{C}_{2} \mathrm{~S}$ & $\mathrm{C}_{2} \mathrm{AS}$ & $\mathrm{C}_{12} \mathrm{~A}_{7}$ & $\mathrm{C}_{4} \mathrm{~A}_{3} \overline{\mathrm{S}}$ & $\mathrm{C}_{3} \mathrm{FT}$ & $\mathrm{Fe}_{3} \mathrm{O}_{4}$ & CT & Q Phase & $\mathrm{C}_{3} \mathrm{AH}_{6}$ & $\mathrm{AH}_{3}$ & $\begin{array}{l}\mathrm{Ca}_{4} \mathrm{Al}_{2}\left(\mathrm{CO}_{3}\right) \\
(\mathrm{OH})_{12} .5 \mathrm{H}_{2} \mathrm{O}\end{array}$ & $\mathrm{C}_{2} \mathrm{ASH}_{8}$ & $\mathrm{R}_{\mathrm{wp}}$ & $\chi^{2}$ \\
\hline $\begin{array}{l}\text { Fondu- } \\
\text { anhydrous }\end{array}$ & 51.4 & 8 & 8 & 4 & 2.4 & 0.3 & 8.5 & 6.7 & 3.7 & 3.9 & 1.7 & 1.4 & - & - & 2.8 & 1.2 \\
\hline Fondu-0.2 & 17.6 & 4.9 & 5.6 & 1.7 & 3.6 & - & 2.5 & 5 & 3.5 & 2.7 & 31.8 & 19.4 & 3.1 & - & 3.2 & 1.4 \\
\hline Fondu- 0.3 & 8.8 & 2 & 2.8 & 0.4 & 1.8 & - & 2.4 & 5 & 1.2 & 3.2 & 48.2 & 23.2 & 1 & - & 3.6 & 1.6 \\
\hline Fondu- 0.4 & 3.5 & 2.6 & - & - & - & - & - & 4.6 & - & 3.4 & 55.6 & 27.3 & 3 & - & 4.1 & 1.8 \\
\hline Fondu-0.5 & 0.8 & 2.2 & - & - & - & - & - & 4.5 & - & 3.9 & 57.7 & 28.1 & 2.8 & - & 4.3 & 1.9 \\
\hline Fondu-0.6 & 0.9 & 1.4 & 2 & - & - & - & - & 4.5 & - & 2.7 & 56.2 & 28.2 & 2.7 & 1.4 & 4.1 & 1.8 \\
\hline
\end{tabular}


Table 3. Radiolytic yields of different CACs cement pastes calculated with respect to the total mass of material $\left(\mathrm{G}\left(\mathrm{H}_{2}\right)\right.$ and $\left.\mathrm{G}\left(\mathrm{H}_{2}\right)_{\text {normalized }}\right)$. Data from literature are given for Portland and CSA pastes and for various formulation of MPC. All samples were small cylinders stored under endogeneous conditions. $\gamma$ irradiations were performed using an external ${ }^{60} \mathrm{Co}$ source (dose rate $=0.25 \mathrm{~Gy} / \mathrm{s}$ ).

\begin{tabular}{|c|c|c|c|c|c|c|c|}
\hline $\begin{array}{l}\text { Type of } \\
\text { cement }\end{array}$ & Cement/mix & $\begin{array}{l}\text { Mass fraction of } \\
\text { water }(\%)\end{array}$ & Curing & $\begin{array}{c}\mathrm{G}\left(\mathrm{H}_{2}\right) \\
\left(\mathrm{x} 10^{-7} \mathrm{~mol} / \mathrm{J}\right)\end{array}$ & $\begin{array}{l}\mathrm{G}\left(\mathrm{H}_{2}\right)_{\text {normalized }} \\
\left(\mathrm{x} 10^{-7} \mathrm{~mol} / \mathrm{J}\right)\end{array}$ & Dose $(\mathrm{kGy})$ & References \\
\hline \multirow{5}{*}{ CAC } & \multirow{5}{*}{$\begin{array}{l}\text { Calcium aluminate cement } \\
\text { "Ciment Fondu }{ }^{\circledR "}\end{array}$} & 16.6 & $\begin{array}{c}\text { Room } \mathrm{T} \text { in } \\
\text { airtight containers }\end{array}$ & $0.0091 \pm 0.005$ & $0.055 \pm 0.005$ & 500 & \multirow{5}{*}{ Our results } \\
\hline & & 23.0 & for one week, & $0.018 \pm 0.002$ & $0.078 \pm 0.008$ & 500 & \\
\hline & & 28.4 & ${ }^{\circ} \mathrm{C}$ for one week & $0.032 \pm 0.003$ & $0.11 \pm 0.01$ & 500 & \\
\hline & & 33.1 & containers & $0.057 \pm 0.006$ & $0.17 \pm 0.01$ & 150,300 & \\
\hline & & 37.3 & & $0.083 \pm 0.008$ & $0.22 \pm 0.02$ & 150,300 & \\
\hline \multirow{5}{*}{ Portland } & \multirow{5}{*}{ CEM I 52,5 N-SR0 CE PM-CP2 NF, Vicat } & 16.7 & & $0.052 \pm 0.01$ & $0.31 \pm 0.03$ & 500 & \multirow{7}{*}{ Chartier, 201$\}$} \\
\hline & & 23.1 & & $0.07 \pm 0.01$ & $0.30 \pm 0.04$ & 500 & \\
\hline & & 28.6 & & $0.10 \pm 0.01$ & $0.32 \pm 0.03$ & 500 & \\
\hline & & 33.3 & & $0.11 \pm 0.01$ & $0.32 \pm 0.03$ & 500 & \\
\hline & & 37.5 & $\begin{array}{l}\text { Airtight at } 20 \text { to } \\
25^{\circ} \mathrm{C} \text { during at } \\
\text { least } 3 \text { months }\end{array}$ & $0.11 \pm 0.01$ & $0.30 \pm 0.03$ & 500 & \\
\hline \multirow{3}{*}{ CSA } & Alpenat $\mathrm{CK}$ without $\mathrm{CaSO}_{4}$ & 28.6 & before irradiation & $0.083 \pm 0.003$ & $0.29 \pm 0.01$ & 97,207 & \\
\hline & $85 \%$ Alpenat CK $+15 \% \mathrm{CaSO}_{4}$ & 28.6 & & $0.106 \pm 0.007$ & $0.37 \pm 0.01$ & 97,207 & \\
\hline & M-1 (mortar + fly ash) & 17.6 & & $0.0105 \pm 0.001$ & $0.059 \pm 0.005$ & 170 to 5090 & \multirow{2}{*}{ Chartier, 202} \\
\hline \multirow{2}{*}{ MPC } & P-1 (stoichiometric cement paste) & 40.5 & & $0.084 \pm 0.010$ & $0.21 \pm 0.03$ & 150,300 & \\
\hline & $\begin{array}{l}\text { Stoichiometric cement paste }+\mathrm{H}_{3} \mathrm{BO}_{3} \text { and } \\
\text { fly ash }\end{array}$ & 23.3 & & $0.02 \pm 0.002$ & $0.086 \pm 0.009$ & 500,1000 & Acher, 2017 \\
\hline $\begin{array}{l}\text { Bulk water } \\
\text { (pH 13) }\end{array}$ & & & & 0.44 & & & $\begin{array}{l}\text { Bjergbekke, } \\
1984\end{array}$ \\
\hline
\end{tabular}


Table 4. $\mathrm{H}_{2}$ radiolytic yields of CAC's hydrates: $\mathrm{AH}_{3}, \mathrm{C}_{3} \mathrm{AH}_{6}$ and monocarboaluminate. $\mathrm{G}\left(\mathrm{H}_{2}\right)_{\text {normalized }}$ were calculated by normalizing apparent hydrogen radiolytic yields by the experimentally water mass fraction determined by TGA up to $600{ }^{\circ} \mathrm{C}$. Selected data of Magnesium phosphate, Sulfoaluminate and

Portland cement hydrates from literature, acquired in comparable conditions, are also reported. For C-S-H, the $\mathrm{CaO} / \mathrm{SiO}_{2}(\mathrm{C} / \mathrm{S})$ ratios are mentioned in

\begin{tabular}{|c|c|c|c|}
\hline Sample & $\begin{array}{c}\mathrm{G}\left(\mathrm{H}_{2}\right) \\
\left(\mathrm{x} 10^{-7} \mathrm{~mol} / \mathrm{J}\right)\end{array}$ & $\begin{array}{l}\mathrm{G}\left(\mathrm{H}_{2}\right)_{\text {normalized }} \\
\left(\mathrm{x} \quad 10^{-7} \mathrm{~mol} / \mathrm{J}\right)\end{array}$ & $\begin{array}{l}\text { Mass fraction of water determined by } \\
\text { TGA up to } 600^{\circ} \mathrm{C}(\%)\end{array}$ \\
\hline $\mathrm{AH}_{3}$ & $0.009 \pm 0.005$ & $0.027 \pm 0.003$ & 32.9 \\
\hline $\mathrm{C}_{3} \mathrm{AH}_{6}$ & $0.003 \pm 0.002$ & $0.011 \pm 0.001$ & 25.4 \\
\hline Monocarboaluminate & $0.12 \pm 0.01$ & $0.38 \pm 0.04$ & 31.4 \\
\hline K-struvite & $0.052 \pm 0.005$ & $0.13 \pm 0.01$ & Acher, 2017b \\
\hline Ettringite & $0.32 \pm 0.03$ & $0.72 \pm 0.07$ & Acher, 2017b \\
\hline Portlandite & $0.042 \pm 0.004$ & $0.19 \pm 0.03$ & Acher, 2017a \\
\hline C-S-H (0.80) & $0.61 \pm 0.06$ & $3.23 \pm 0.32$ & Yin, 2019 \\
\hline C-S-H (0.97) & $0.58 \pm 0.06$ & $3.11 \pm 0.31$ & Yin, 2019 \\
\hline C-S-H (1.14) & $0.49 \pm 0.05$ & $2.85 \pm 0.29$ & Yin, 2019 \\
\hline C-S-H (1.30) & $0.42 \pm 0.04$ & $2.44 \pm 0.24$ & Yin, 2019 \\
\hline C-S-H (1.40) & $0.36 \pm 0.04$ & $2.13 \pm 0.21$ & Yin, 2019 \\
\hline Bulk water (pH 13) & 0.44 & & Bjergbekke, 1984 \\
\hline
\end{tabular}

Table 5. Mass fraction of hydrates corrected considering the mass fraction of Free Water $\left(\mathrm{X}_{\mathrm{FW}}\right)$. The mass fraction of the sum of hydrates $\left(\mathrm{X}_{\text {Tot. hyd. }}\right)$, of the solid phase $\left(\mathrm{X}_{\text {Solid }}\right)$, of Free Water $\left(\mathrm{X}_{\mathrm{FW}}\right)$, of Bound Water $\left(\mathrm{X}_{\mathrm{BW}}\right)$ and of the total of water $\left(\mathrm{X}_{\text {Tot. }}\right.$.) are also reported.

\begin{tabular}{|c|c|c|c|c|c|c|c|c|}
\hline Sample & $\mathrm{X}_{\mathrm{C} 3 \mathrm{AH} 6}$ & $\mathrm{X}_{\mathrm{AH} 3}$ & $\begin{array}{c}\mathrm{X}_{\mathrm{Ca} 4 \mathrm{Al} 2(\mathrm{CO} 3)} \\
(\mathrm{OH}) 12.5 \mathrm{H} 2 \mathrm{O}\end{array}$ & $\mathrm{X}_{\text {Tot. hyd. }}$ & $\begin{array}{c}\mathrm{X}_{\text {Solid }} \\
\text { (= corrective } \\
\text { factor) }\end{array}$ & $\mathrm{X}_{\mathrm{FW}}$ & $\mathrm{X}_{\mathrm{BW}}$ & $\begin{array}{c}\mathrm{X}_{\text {Tot. } \mathrm{w} .} \\
=\mathrm{X}_{\mathrm{BW}}+\mathrm{X}_{\mathrm{FW}}\end{array}$ \\
\hline Fondu- 0.2 & 0.32 & 0.19 & 0.03 & 0.54 & 1 & 0 & 0.17 & 0.17 \\
\hline Fondu- 0.3 & 0.48 & 0.23 & 0.01 & 0.72 & 1 & 0 & 0.23 & 0.23 \\
\hline Fondu-0.4 & 0.52 & 0.26 & 0.03 & 0.81 & 0.94 & 0.06 & 0.23 & 0.29 \\
\hline Fondu- 0.5 & 0.51 & 0.25 & 0.03 & 0.79 & 0.88 & 0.12 & 0.21 & 0.33 \\
\hline Fondu-0.6 & 0.46 & 0.23 & 0.02 & 0.71 & 0.83 & 0.17 & 0.20 & 0.37 \\
\hline
\end{tabular}

